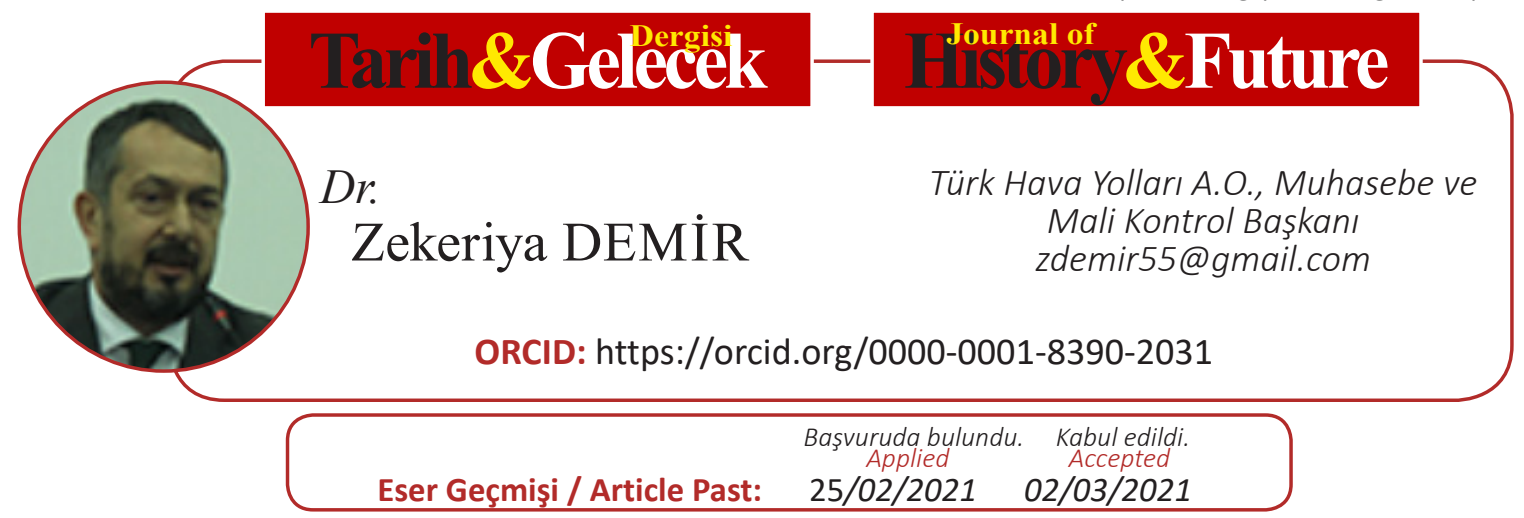

Araştırma Makalesi

DOI: http://dx.doi.org/10.21551/jhf.886638

Research Paper

Orjinal Makale / Orginal Paper

\title{
İttihat ve Terakki Dönemi İktisat Politikası Tartışmaları
}

\section{Economic Policy Discussions in Ittihat-Terakki Era}

\section{$\ddot{O} z$}

Osmanlı Devletinin son dönemine damgasını vuran İttihat ve Terakki'nin ortaya çıkmasında, Batılılaşma hareketleri ile Fransız İhtilali'nin ortaya çıkardığı milliyetçilik akımlarının önemli etkileri olmuştur. Siyasal düşüncelerinin şekillenmesinde, Avrupa'da ortaya çıkan meşrutiyet yönetimlerinin, ekonomik sistem düşüncelerinin şekillenmesinde de Osmanlı Devleti'nin Batı karşısındaki ekonomik gerilemesinin etkileri görülmektedir. Bu reel duruma bir tepki olarak Milli İktisat daha doğru bir ifade ile korumacı iktisat politikalarına yönelmişlerdir. Batı ile ilgili düşüncelerinin oluşmasında, Harbiye, Tıbbiye ve Mülkiye mekteplerinde görev yapan yabancı hocaların önemli etkilerinin olduğu anlaşılmaktadır. Ancak referans kabul ettikleri batılı düşünce ve değerler sistemi konusunda derinlikli bir bilgiye sahip olamadıkları gibi bu değerler ile geleneksel değerler arasındaki çatışmadan kurtulamamışlardır. Bu nedenle bütün idealist kaygılarına rağmen önerdikleri fikirler eklektik ve pragmatik olmaktan öteye gidememiştir.

Bu çalışmada İttihat ve Terakki döneminde ülkenin ekonomik açıdan kalkınması ile ilgili olarak ileri sürülen iktisat politikaları incelenmiş siyasal, sosyal ve felsefi konulara ekonomi politikalarını etkilediği ölçüde değinilmiştir. İttihat ve Terakki’nin ekonomi politikalarına ilişkin düşüncelerinin iktidara gelene kadar olgunlaştığını söylemek zordur. İttihat ve Terakki içinde ekonomik sistem tercihleri açısından liberal iktisat ve milli iktisat taraftarları olmakla beraber uygulamada milli iktisat politikaları daha etkili olmuştur. Sosyalist iktisada yönelik düşünceler toplumun sosyo-ekonomik yapısı itibariyle gelişeceği uygun bir zemin bulamamıştır. İttihat ve Terakki dönemi boyunca ekonomi yönetimi açısından tek bir uygulamadan ziyade günün şartlarına uygun farklı politikalar ve uygulamalar geliştirilmiştir. Özetle ekonomik sistem ve politika tercihlerinde derinlikli bir bakış açısından ziyade, konjonktüre uygun olarak pragmatik ve eklektik bir yol tercih edilmiştir.

Anahtar Kelimeler: İttihat ve Terakki, İktisat Politikası, Liberaller, Milli İktisatçılar, Sosyalistler

* Bu makale, Prof. Dr. Tiğinçe Oktar danışmanlığında yürütülen "ittihat ve Terakki Dönemi Iktisat Politikası Tartş̧maları", Marmara Üniversitesi, Sosyal Bilimler Enstitüsü, Iktisat Anabilim Dalı, iktisat Tarihi Bilim Dalı, 2003 isimli doktora tezinden üretilmiştir.

ATIF: DEMiR, Zekeriya, "Ittihat ve Terakki Dönemi Iktisat Politikası Tartışmaları", Tarih ve Gelecek Dergisi, 7/1 (Mart 2021), s. $(180-220)$

CITE: DEMiR, Zekeriya, "Economic Policy Discussions in İttihat-Terakki Era”, Journal of History and Future, 7/1 (March 2021), pp. (180-220) 


\section{Abstract}

Ittihat and Terakki, which left its mark on the last period of the Ottoman State, can be regarded as a reflection of the Ottoman Westernization efforts at home and the modern nationstate ideas that emerged from the outside with the effect of the French Revolution. The effects of the economic regression of the Ottoman Empire against the West are observed in the shaping of political thoughts as in the shaping of nationalism movements and economic system ideas that emerged in Europe. As a reaction to this real situation, they turned to National Economy, more accurately, protectionist economic policies. It is understood that the foreign professors working in the schools of War, Medicine and Civil Service had an important influence on the formation of these thoughts about the West. However, they did not have in-depth knowledge about the western thought and value system, which they accepted as reference, and could not get rid of the conflict between these values and traditional values. For this reason, despite all their idealistic concerns, the ideas they suggested could not go beyond being eclectic and pragmatic.

In this study, the economic policies put forward in relation to the economic development of the country in the period of Ittihat and Terakki were examined and the political, social and philosophical issues were touched as they affect the economic policies. It is difficult to say that Ittihat and Terakki's thoughts on economic policies matured until they came to power. Although there were supporters of liberal and national economics in terms of economic system preferences within the party, national economic policies were more effective in practice. The ideas about the socialist economy could not find a suitable ground to develop due to the society's socio-economic structure. During the period of Ittihat and Terakki, different policies and practices were developed around daily needs and requirements rather than a single application in terms of economic management. In summary, pragmatic and eclectic path has been preferred along with the conjuncture, rather than a deep perspective on economic system and policy choices.

Keywords: Ittihat and Terakki, Economic Policy, Liberals, Nationalists, Socialists

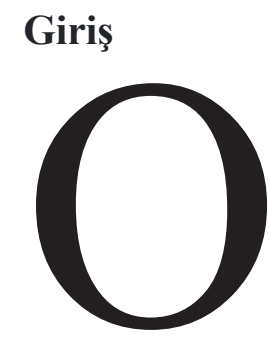

smanlı Devleti'nde bir sistem dönüşümünü sağlayan İttihat ve Terakki'nin serüveni hem Osmanlı batılılaşma çabalarını anlamanın hem de Cumhuriyet döneminin ekonomik, sosyal ve siyasal yapılanmasının anlaşılması bakımından ciddi bir önem taşımaktadır. İttihat ve Terakki idealist kaygılar taşıyan Askeriye, Tıbbıye ve Mülkiye öğrencileri tarafından ülkeyi kurtarmak amacıyla kurulmuş bir gençlik örgütünden çok kısa bir süre sonra kendisini ülke yönetiminde bulmuştur. Ülke yönetimini ele alana kadar bir ekonomik sistem tercihinden ziyade siyasal sistem ve egemenliğin kimin tarafından kullanılacağı konusu üzerinde kafa yordukları ve tercihlerinin batıdan yana olduğu bilinmektedir. Çünkü Osmanlı Devleti’nin ekonomik olarak geri kalmışlığını batılı kurum ve sistemlerin olmayışı ile açıklamaya çalışmaktadırlar. İttihatçılarda, batılı fikirlerin oluşmasında yukarıda sayılan okullarda çalışan yabancı hocaların önemli etkileri olmuştur. Her ne kadar batılı fikirlerden önemli derecede etkilenmiş olsalar da bu fikirler konusunda derinlikli bir bilgiye sahip oldukları söylenemez. İttihat ve Terakki sosyo-ekonomik ve sosyo-kültürel açıdan yüksek tabakaya dayanan bir toplumsal tabana sahip değildir. Hem bu nedenlerden dolayı hem de ülkenin içinde bulunmuş olduğu şartlardan dolayı problemlere acil çözüm bulma ihtiyacı İttihatçıları, 
pragmatik ve eklektik bir yapıya zorlamıştır. Bu çalışmada, İttihat ve Terakki dönemindeki liberaller, milli iktisatçılar ve sosyalistler tarafından ortaya atılan iktisat politikalarına yönelik öneriler, bu alandaki literatür, süreli yayınlar ve hatıratlar üzerinden incelenmiştir. Çalışma bu haliyle dönemin iktisat politikası tartışmalarına yönelik literatüre bir katkı sunmayı amaçlamaktadır.

Çalışmanın birinci bölümünde, İttihat ve Terakki'nin 1889 yllında Askeri Tibbiye'de bir öğrenci faaliyeti olarak başlayan ve 1908 'de bir devrimi gerçekleştirerek ülkenin siyasal hayatına egemen olması sürecinde etkili olan faktörler incelenmiştir. İkinci bölümde ise İttihat ve Terakki dönemindeki liberaller, milli iktisatçılar ve sosyalistler tarafından önerilen iktisat politikaları ilgili literatür, süreli yayınlar ve hatıratlar üzerinden ve ulaşılabilen kaynaklar ışığında karşılaştırmalı olarak incelenmiştir. Bu bölümde her bir görüş ortaya çıkış süreci, önemli temsilcileri, iktisat politikası önerileri ve bu görüşlere yöneltilen eleştiriler şeklinde ele alınmıştır. Bu çalışma ile İttihat ve Terakki döneminde ortaya çıkan bu üç temel düşünce sahiplerinin savundukları ideolojilerin temel varsayımlarından ve teorik bütünlüğünden hareketle bir iktisat politikası önerilerinin olup olmadığ 1 , birbirlerine yönelik eleştirileri ve bu eleştirilerin dayanaklarının ortaya çıkarılması amaçlanmaktadır.

\section{1.İttihat ve Terakki'nin Oluşumuna Neden Olan Faktörler}

İttihat ve Terakki'nin oluşumuna neden olan faktörleri içsel ve dışsal faktörler olarak ele almak mümkündür. İçsel faktörler arasında Osmanlı Devleti'nin batı karşısındaki gerilemesine karş1 verilen tepkinin önemi büyüktür. $\mathrm{Bu}$ ekonomik gerileme beraberinde bazı toplumsal huzursuzlukları getirmiş ve bu durum istismar edilerek "Devr-i dilara-yı meşrutiyette vergi verilir mi? " gibi çarpık bir anlayışa evrilmiş ve bu kavram zengin fakir birçok insanın işine gelmiş ve devletin vergi tahsilatının durmasına neden olmuştur. ${ }^{1} \mathrm{Bu}$ kapsamda vergilerin yüksekliği bahane edilerek Erzurum'da başlayan olaylar, istibdadın kaldırılmasına yönelik eylemlere dönüşmüş ve bu eylemlerde 1905 Rus Devriminin etkileri görülmüsstür. ${ }^{2}$ 1906-1907 yıllarında Anadolu'nun farklı bölgelerinde ortaya çıkan hükümet karşıtı olaylarda Anadolu'ya sürülen Jön Türkler'in ${ }^{3}$ ve Prens Sebahattin tarafından organize edilen Teşebbüs-i Şahsi ve Adem-i Merkeziyet Cemiyeti'nin etkilerinin olduğu bilinmektedir. ${ }^{4}$ Özetle, ekonomik problemler ve vergilerin yüksekliği gibi konular üzerinden başlayan huzursuzluklar zamanla bir toplumsal hareketlenmeye neden olmuştur.

İttihat ve Terakki'nin oluşumuna katkı yapan dışsal nedenler arasında masonluğun önemli bir rolü olduğu bilinmektedir. Karabekir, İttihat ve Terakki içinde masonların bulunduğunu ve bunların İttihad-1 İslam politikasına taraftar olduklarını belirtmektedir. ${ }^{5}$ Masonlarla ilişkiler 1906'da Selanik'te kurulan Osmanlı Hürriyet Cemiyeti aracılığı ile olmuştur. ${ }^{6}$ Yalçın, anılarında kendisinin de mason olduğunu, çünkü hem İttihat ve Terakki içinde hem de bürokrasi ve siyasette

1 Süleyman Kani İrtem, Meşrutiyet Doğarken 1908 Jön Türk İhtilali, Osman Selim Kocahanoğlu (Haz.), Temel Yayınları, İstanbul (1999), 199.

2 H. Zafer Kars, 1908 Devriminin Halk Dinamiği, Kaynak Yayınları, İstanbul, 2. Bask1 (1997), 35.

3 Yuriy Asetoviç Petrosyan, Sovyet Gözüyle Jön Türkler, Çev. Mazlum Beyhan-Ayşe Hacıhasanoğlu, Bilgi Yayinevi, Ankara (1974), 234-235.

4 Kars, 26, Erol Özbilgen, Pozitivizmin Kıskacında Türkiye, Ağaç Yayıncılık, İstanbul (1994), 101.

$5 \quad$ Kazım Karabekir, İttihad ve Terakki Cemiyeti, Türdav Ofset, İstanbul (1982),187.

6 Muammer Göçmen, Itttihat ve Terakki’nin Son Yllları (1916 Kongre Zabıtlart), Eşref Yağcığlu (Haz.), Nehir Yayınları, İstanbul (1992), 48. 
yükselmenin anahtarının masonluk olduğunu belirtmektedir. ${ }^{7}$ Ahmad, Yahudiler ve Masonların İttihat ve Terakki'yi desteklediğini ve Yahudilerin, Osmanlı'nın bir yarı sömürge olmasını kendileri açısından bir tehdit olarak gördükleri için Siyonist hareketin Osmanlı Yahudileri arasında çok fazla ilgi görmediğini ${ }^{8}$ ileri sürmektedir. Ancak Mevlanzade Rıfat bu görüşte değildir. Ona göre, Siyon Cemiyeti Sandanski vasıtasıyla 1902 Makedonya ihtilalinde başarılı olamayınca, Rumeli'de bulunan 3. Ordu'yu hükümete karşı kışkırtmak için Emanuel Karasu ile birçok faaliyet planlamıştır. Bu amaçla, Selanik’teki dönmelerin maddi destekleri ile İttihat ve Terakki'nin Manastır, Üsküp ve İşkodra şubelerinin açılışı sağlanmıştır. ${ }^{9}$ Paul Dumont'ta, Selanik' in Yunanlılar tarafından alınması ve Büyük Bulgaristan'ın kurulması halinde Yahudiler hem Makedonya hinterlandından hem de yakın doğunun önemli ticaret merkezlerinden mahrum kalacağı için Balkanlarda statükonun devamından yana olmuşlardır. ${ }^{10}$ İttihatçılar, Ermeni mason örgütleri ${ }^{11}$ ve İtalyan Masonları ile de önemli ilişkiler kurmuştur. ${ }^{12}$ Özellikle İtalyan Masonluğunun, İttihat ve Terakki'nin doğuşunda doğrudan etkisinin olduğu ve bu sayede İmparatorluk içinde gizlice çalışabilme imkânı bulduğu iddia edilmektedir. ${ }^{13}$ Ancak Lewis, İttihat ve Terakki üzerindeki bu Yahudi ve yabanc1 etkisine karş1 çıkmakta, Osmanlı gayrı müslimlerinin küçük ve zamanla azalan bir etkisinden bahsetmektedir. ${ }^{14}$

Herhangi bir sosyal ya da politik hareketin ortaya çıkması ve gelişmesi çevresinde oluşan toplumsal hareketlerden bağımsız olarak düşünülemez. Bu anlamda İttihat ve Terakki'nin, 1906 yılı Ekim ayında İran'da gerçekleşen devrimle yakından ilgilendiği görülmektedir. Mardin'e göre, İttihat ve Terakki'nin kuruluşuna etki eden faktörler arasinda yer alan İran etkisinde, Cemaleddin Efgani’nin önemli bir rolü vardır. Çünkü Efgani, Jön Türkler tarafından benimsenen Türkçülük fikirlerinin gelişmesine katkıları olan kişiler arasında yer almaktadır. ${ }^{15}$ Bunun yanında, Jön Türkler Japon ilerleme modeli ile İran ve Rusya'nın anayasal rejimler kurma yönündeki çabalarını da dikkatle izlemişlerdir. ${ }^{16}$ Öyle ki İran ve Rus Devrimleri İttihatçıların, Türkiye'de

7 Hüseyin Cahit Yalçın, Siyasal Anılar, Türkiye İş Bankası Kültür Yayınları, İstanbul, 2. Baskı (2000),164165.

8 Feroz Ahmad, Itttihatçıllktan Kemalizm'e, Çev. Fatmagul Berktay (Baltali), Kaynak Yayınları, İstanbul, 4. Bask1 (1999), 20-30.

9 Mevlanzade Rıfat, Itttihat Terakki İktidarı ve Türkiye İnkılabının İçyüzü, Yedi İklim Yayınları, İstanbul (1993), 112-13, Selanik Merkez ile, Manastır, Üsküp ve İşkodra şubelerini idare edenler için bkz.s. 113114.

10 Paul Dumont, "Yahudi, Sosyalist ve Osmanlı Bir Örgüt: Selanik İşçi Federasyonu", Osmanlı İmparatorluğu'nda Sosyalizm ve Milliyetçilik (1876-1923), Mete Tunçay, Erik Jan Zürcher (Der.), Illetişim Yayınlarl, Istanbul, 2.Baskı (2000), içinde, 77-78.

11 Mehmet Memduh, Tanzimat'tan Meşrutiyete 1, Sadeleştiren Hayati Develi, Nehir Yayınları, İstanbul (1990), 104-105, 154-155.

12 Orhan Koloğlu, Osmanlı -ittalyan Libya Savaşında İttihatçılar, Masonlar ve Sosyalist Enternasyonel, Ümit Yayıncılık, Ankara (1999), 83-84.

13 lacovella, Angelo, Gönye ve Hilal: Ittihad-Terakki ve Masonluk, Çev. Tülin Altınova, Tarih Vakfı Yurt Yayınları, İstanbul (1998), 33-37., 19. yüzyılda Türkiye'deki mason locaları ile ilgili olarak s.25’teki Tablo l'de ayrıntıli bilgi mevcuttur.

14 Bernard Lewis, Modern Türkiye’nin Doğuşu, Türkçesi, Metin Kıratlı, Türk Tarih Kurumu Yayınları, Ankara, 7. Bask1 (1998), 212.

15 Şerif Mardin, Jön Türkler’in Siyasî Fikirleri (1895-1908), İletişim Yayınları, İstanbul, 5. Baskı (1996), 65.

16 Feroz Ahmad, İttihatçılıktan Kemalizm'e, Çev. Fatmagul Berktay (Baltali), Kaynak Yayınları, İstanbul, 4. Bask1 (1999), 8. 
de bir meşruti idare kurulabileceğine dair inançlarını güçlendirmiştir. ${ }^{17}$ Ayrıca, 1902-1903 yıllarında kendini duyurmaya başlayan Rusya'daki devrim olayları Türk subaylarının hükümete karşı olan düşüncelerinin gelişmesinde etkili olmuştur. ${ }^{18}{ }^{\mathrm{Bu}}$ nedenle, Mısır'da çıkan ve Türk millî burjuvazisinin çıkarlarını temsil eden Türk gazetesi, 1905 Rus Devriminin düşüncelerini öven yazılara yer vermiştir. ${ }^{19}$ Görüleceği üzere, İran ve Rus devrimlerinin İttihat ve Terakki üzerinde etkileri olmuş ve Türkiye'de de böyle bir devrimin başarılabileceği konusunda kendilerine bir umut vermiştir.

\section{1.İttihat ve Terakki'nin Kuruluşunu Hazırlayan Kişiler}

Sosyal ve siyasal hareketlerin ortaya çıkması ve gelişmesinde kişilerin rolü kuşkusuz ki çok önemlidir. Bu anlamda Mizancı Murat, İttihat ve Terakki açısından önemli isimlerden biridir. Mizancı Murat'ın İttihat ve Terakki ile irtibatı 1893-1894 yılları arasında olmuş ve örgüte geç katılmasında devlet memuru olması ile Abdülhamit'in politikasını değiştireceğine dair beklentisi etkili olmuştur. ${ }^{20}$ Mizancı Murat Jön Türkler'e geç katılmasına rağmen etkili isimlerden biri olmuştur. Ramsaur'a göre bunun nedeni, Ahmet Rıza'nın aksine Pan-İslâmist olmasıdır. Bu yüzden Murat'ın fikirleri Ahmet Rıza'nın fikirlerine göre hem dinsel hem de milliyetçi duygular açısından daha fazla ilgi çekmiştir. ${ }^{21}$ Murat Bey, Pan-İslâmist olmasına rağmen fikirlerinde Türklük özel bir yer tutmakta ve şu şekilde ifade edilmektedir: "Arapların her türlü hikem ve tedaini istişare edelim fakat Türk olduğıтиzи unutmayalım " Murat Bey'in bu fikirlerinde Slavofillerin etkisinin olduğu görülmekte ve Rusya'da Rusluğun teşvikine karşılık Türkiye'de Türklük teşvik edilmektedir. ${ }^{22} \mathrm{Bu}$ ifadeler İttihat ve Terakki içindeki milliyetçi eğilimleri göstermesi açısından önemlidir.

İttihat ve Terakki açısından Ahmet Rıza'nın önemi hem fikirlerinden hem de karşı olduğunu söylediği Abdülhamit'e karşı birçok kişinin yarıda bıraktığı mücadeleyi 1908 ihtilaline kadar istikrarlı bir şekilde sürdürmesindendir. Özbilgen'e göre Ahmet Rıza, Pierre Laffitte'in, Prens Sabahattin de Le Play ve Demolins'in konferanslarından, sohbetlerinden ve çevresinde kurdukları dostluk ilişkileri sırasında edindikleri bilgilerle Osmanlı entelektüellerini yönlendirmişler ve bu bilimsel görünüşlü siyasal kudret mücadelelerini, Sultan Abdülhamit'e karşı kişisel ve ortak nedenlerle yıllar yılı sürdürmüşlerdir. ${ }^{23}$ Bilindiği üzere Ahmet Rıza, Auguste Comte'un kurmuş olduğu Pozitivist Cemiyeti'nde, Avrupa Birleşik Devletleri Komitesi’ne Türkiye temsilcisi olarak seçilmiş ve bu temsilcilik ona, Abdülhamit'e karşı yürüteceği mücadelede hem Fransız pozitivistlerinin hem de masonların desteğini sağlamıştır. ${ }^{24}$ Ancak Akşin, gerek Ahmet Rıza ve gerekse İttihat ve Terakki açısından Avrupa düşünce hareketlerinin etkisinin çok fazla abartılmaması gerektiğini belirtmektedir. ${ }^{25}$ Ancak buna rağmen Ahmet Riza'ya pozitivist olmasından dolayı

17 Çağlar Keyder, Türkiye'de Devlet ve Sinıflar, İletişim Yayınları, İstanbul, 3. Bask1 (1993), 79. Aykut Kansu, 1908 Devrimi, Çev. Ayda Erbal, İletişim Yayınları, İstanbul, 2. Baskı (2001), 77-78.

18 Petrosyan, 232.

19 Kars, 105-106.

20 Petrosyan, 188.

21 E.E. Ramsaur, Jön Türkler ve 1908 İhtilali, Çev. Nuran Yavuz, Sander Yayınları, İstanbul, 2. Bask1 (1982), 54.

22 Şerif Mardin, Jön Türkler'in Siyasî Fikirleri, 110-115.

23 Özbilgen, 106.

24 Özbilgen, 96-97.

25 Sina Akşin, Jön Türkler ve İttihad Terakki, İmge Kitabevi, Ankara, 2. Baskı (1998), 41. 
İttihat ve Terakki içinde daima tereddütle yaklaşııııștır. Çünkü bundan dolayı halk nezdinde dinsiz olarak yorumlanması halinde, bu algının kendilerini Abdülhamit karşısında zor durumda bırakacağından korkmuşlardır. ${ }^{26}$ Bayur, Ahmet Rıza'nın evrensellik iddiası ile yüzyılın arifesinde ortaya çıkan imparatorlukların çözülmesi ve her halkın kendi etnik, dini ve kültürel değerlerini kendisinin belirlemesi ilkesi ile çatıştığını belirtmektedir. Çünkü Ahmet Rıza'nın Osmanlı İmparatorluğu bünyesinde olmasını beklediği birliği, Makedonya ve Ermeni Komiteleri kendi milletleri için muhtariyet şeklinde talep etmekteydiler. ${ }^{27}$ Benzer şekilde, Ahmet Rıza'nın, Osmanlı toplumuna pozitivizmin uyarlanması konusunda Fransa'yı örnek alması da Fransa'nın yaşamış olduğu tarihi, ekonomik ve sosyal tecrübeleri dikkate almadığı için eleştirmektedir. ${ }^{28}$ İttihat ve Terakki'nin ideolojik ve entelektüel olarak en ön planda yer alan temsilcilerine yönelik bu eleştiriler, İttihatçıların Batının yaşamış olduğu tarihsel tecrübe ve birikimini anlamakta ne kadar yüzeysel olduklarına dair bir işarettir.

Prens Sabahattin İttihat ve Terakki Cemiyeti içinde en çok tartışılan isimlerden biri olmasına rağmen Cemiyet içinde hiçbir zaman çok önemli bir yer işgal etmemiştir. Prens Sabahattin'in esas düşüncesi önce dağınık haldeki Jön Türk çalışmalarını bir araya getirmek ve bir plan ve program dahilinde hareket etmektir. Bu amaçla yayınlamış olduğu beyannamelerde hedeflerini "tabiiyeti Osmaniye altında bir adaleti mütesaviye ile yaşamaktır" cümlesi ile ifade etmiştir. Bu cümleden de anlaşılacağı üzere Prens Sabahattin ve Lütfullah Beyler Osmanlı Devleti'nin bekasından yana olmakla birlikte idare tarzında bir değişikliği arzulamaktadırlar. ${ }^{29}$ Prens Sabahattin, bağlı olduğu Le Play okulunun ve dolayısı ile Demolins'in etkisinde kalarak Osmanlı Devleti'nin içinde bulunduğu durumdan kurtulması için meşrutiyetin ilanını yeterli görmemektedir. Bunun için devlet yönetiminde adem-i merkeziyetçi bir yapının kurulmasını, kişilerde şahsi teşebbüsü geliştirecek tedbirler alınmasın ${ }^{30}$ ve böyle bir dönüşümü sağlamak için de bütün okullarda hiçbir ayırım gözetmeksizin müteşebbis ve üretici insanlar yetiştirecek bir sisteme ihtiyaç olduğunu belirtmektedir. ${ }^{31}$ Prens Sabahattin'e göre Osmanlı'da, teşebbüs fikrinin gelişmemesi ve müteşebbis yetişmemesinin nedenleri, Anadolu köylüsündeki ahlak anlayışının sonucu olarak dünyevi

26 Ramsaur, 45.

27 Y. Hikmet Bayur, Türk Inkılabı Tarihi, Cilt: II, Kısım IV, Türk Tarih Kurumu Yayınları, Ankara, 2. Bask1 (1983), 18.

28 Özbilgen, 82-83.

29 Ahmet Bedevi Kuran, İnkılap Tarihimiz ve Jön Türkler, Kaynak Yayınları, İstanbul, 2. Baskı (2000), 170-171; Bayram Bayraktar, "Günümüzde Yeniden Değerlendirilmesi Gereken Bir Düşünür: Prens Sabahattin Bey", Ankara Üniversitesi, Dil Tarih Coğrafya Fakültesi, Tarih Bölümü, Tarih Araştırmaları Dergisi, Cilt:XVIII, Sayı:29, (1996), 51-61; Cenk Reyhan, “Türk Siyasal Düşüncesinde Yol Ayrımı, Aykırı Bir Aydın Prens Sabahattin ve Düşüncesi”, Türkiye Günlügü̈, Sayl:21-22, Klş 1992-Bahar 1993, 121-26., Cengiz Çağla, "Bir Türk Aydını Olarak Prens Sabahattin Bey”, Türkiye Günlüğ̈̈, Sayı:26, Ocak-Şubat 1994, 30-34; Cavit Tütengil, "Prens Sabahattin (1877-1948)", İstanbul Üniversitesi Edebiyat Fakültesi Yayınları Sosyoloji Dergisi, Sayı:4-5, 1947-1949, 176-220; Cahit Tanyol, "İçtimai Monografi Hazırlıkları, Prens Sabahattin”, İstanbul Üniversitesi Edebiyat Fakültesi Yayınlan Sosyoloji Dergisi, Sayı:4-5, 19471949, 145-175.

30 Aksin, s.63. Ramsaur, s.99-101. Prens Sabahattin, Görüşlerim, Ahmet Zeki İzgeör(Haz.), Buruç Yayınları, İstanbul (1999), 146; Prens Sabahattin ve Le Play okulu ile ilgili olarak bkz. Nurettin Şazi Kösemihal, “.Le Play Okulu ve Türkiye'deki Etkisi”, Toplum Bilim (Türk Toplum Bilimi Özel Saylsl), Sayı:2, Ekim (1993), 22-29; Mithat Baydur, "Geçmişten Günümüze Prens Sabahattin ve Adem-i Merkeziyetçilik", Türkiye Günlü̆̈̈̈, Say1:22, Bahar-1993, 40-45.

31 Prens Sabahattin, 180-181. 
isteklerin zayıf olması, mütevazı hayat tarzının çalışma şekillerini olumsuz yönde biçimlendirmesi ile memurların devlet kapısından ayrılmaları halinde hiçbir iş yapamayacaklarına dair inanç olup bunu düzeltmenin yolu eğitim sisteminde yapılacak değişikliktir. ${ }^{32}$ Prens Sabahattin her ne kadar devletin kurtuluşunu Anglo-Sakson tipi adem-i merkeziyet sisteminde görüyor olsa da Mardin'e göre bu görüşü tezatlarla doludur. Çünkü, 19. Yüzyıl başları ile ortaları gibi İngiltere ve Amerika merkeziyetçilik fikrine geri dönmeye başlamıştı. Bu bakımdan Sabahattin Bey’in iddia ettiği gibi, gelişmişlik düzeyi ile adem-i merkeziyet arasında bir bağ yoktu. ${ }^{33}$ İttihat ve Terakki'nin diğer emli kişilerinde de olduğu gibi Prens Sabahattin'in de rol model olarak aldığı düşünce yapısı ve ekonomik sistemler hakkındaki bilgisi de derinlikli bir bilgiden ziyade pragmatik ve eklektik olduğu görülmektedir.

\subsection{Ittihat ve Terakki’ye Zemin Hazırlayan Yayınlar}

İttihat ve Terakki'nin düşüncelerini yaymak açısından gazetelerin önemi büyüktür. Bu kapsamda 1886-1890 yılları arasında İstanbul'da, 1895'te Mısır ve 1896'da Paris'te çıkarılan Mizan gazetesi İttihat ve Terakki açısından önemli roller üstlenmiştir. Mizan'ın Kahire'deki yazılarının önemli bir kısmı Murat Bey’in imzasını taşırken, Paris'teki yazılar İttihat ve Terakki'nin “Heyet-i Tahririyesi" tarafindan hazırlanmıştır. ${ }^{34}$ Mizan gazetesindeki en önemli eleştiri konusu devlet adamları ve bürokratların, din adamlarının etkisinde kalarak ülkenin ihtiyacı olan 1slahat çabalarını yerine getirmekte yetersiz kaldıkları yönündedir. Din adamlarına yönelik eleştirilere rağmen bu geri kalmışlıkta, İslam dinine ve şeriata yönelik bir eleştiri olmadığı gibi, İslam dininin, ilim ve teknikteki gelişmeleri teşvik ettiğine dikkat çekilmektedir. Bu nedenle geri kalmışlığı İslâmiyet'e değil dirayetli bir hükümetin olmayışına bağlamaktadırlar. ${ }^{35}$ Bütün bu sorunlardan kurtulmak için önerilen çözümler, meşrutiyetin ilanı, Kanun-i Esasi'nin uygulanması ve Osmanlıcılık fikri etrafında, İttihat ve Terakki çatısı altında birleşmek şeklindedir. ${ }^{36}$

Bu dönem açısından önemli gazetelerden biri de 1895 yılında Paris’te çıkarılan Meşveret gazetesidir. Bayur'a göre, gazetenin fikrî ve entelektüel seviyesi yüksek olup Batılı bir zihniyete sahiptir. Gazete İttihat ve Terakki'nin görüşlerini "programımız" başlığı altında duyurmasına rağmen program incelendiğinde, Cemiyetten ziyade Ahmet Rıza'nın görüşlerini yansıttığ1 görülmekte ve Cemiyet ile sadece İmparatorluk vatandaşlarının “Osmanlılaştırılması” konusunda mutabık kalındığ1 anlaşılmaktadır. ${ }^{37}$ Mardin'e göre, "Osmanlılaştırılma” fikri, Comte'un "medeniyetleri zedelemeden gelişme sürecine katma" fikri ile uyumlu olmasının yanında İttihat ve Terakki'nin Osmanlıları üstün tutma isteklerine de karşılık vermektedir. Bu nedenle Ahmet Rıza'nın Comte'cu "gelenekçiliği ” ile İttihatçıların “Osmanlılığın şanını kurtarma isteği” ortak bir paydada buluşmuştur. ${ }^{38}$ Özetle, İttihat ve Terakki üyelerinin büyük çoğunluğunda görülen

32 Bayur, 26., Prens Sabahattin, 44-46.

33 Mardin, Jön Türklerin Siyasi Fikirleri, 298.

34 Hidayet Uğur, “Jön Türklerin Çıkardığı Gazeteler 1, Mizan” Türk Düşüncesi, Cilt: 3, Sayı: 15. 1 Şubat $1955,180$.

35 Hidayet Uğur, “Jön Türkler’in Çıkardığı Gazeteler 1, Mizan II” Türk Düşüncesi, Cilt: 3, Say1:16. 1 Mart 1955. 268-277.

36 Hidayet Uğur, “Jön Türkler'in Çıkardığı Gazeteler 1, Mizan III” Türk Düşüncesi, Cilt: 3, Say1: 17, 1 Nisan 1955, 345-350.

37 Bayur, 68.

38 Mardin, Jön Türkler'in Siyasî Fikirleri, 200. 
pozitivist, Batıcı ve otoriter eğilimlerin benimsenmesinde Meşveret gazetesinin yayınlarının etkili olduğu söylenebilir.

Cenevre'de çıkarılmaya başlayan, sonrasında Kahire'ye nakledilen ve II. Meşrutiyet'le birlikte İstanbul'a taşınan İçtihat dergisi de bu dönem açısından önemli yayınlar arasındadır. ${ }^{39}$ Bilindiği üzere Abdullah Cevdet Türkiye'de biyolojik materyalist düşüncenin temsilcisi olmasına rağmen derginin adını İslâmi bir kavramdan hareketle İçtihat olarak koymuş ve derginin amacını da "içtihat kapısını" tekrar açmak şeklinde belirlemiştir. ${ }^{40}$ Mardin'e göre, Abdullah Cevdet'in düşüncesinin esası halkı eğitmek ve onları medeniyet akımına katmaktı. İçtihat dergisi, 1860'larda yaygın olan Ansiklopedizm akımını benimsemiştir. Bu akıma göre bilimin bir politikası yoktur ve esas olan insanların bilgisinin artırılmasıdır. Abdullah Cevdet'te bu düşünceden hareketle toplumun batılılaşmasını insanların bilgilerinin artırılmasında görmüştür. ${ }^{41} \mathrm{Bu}$ yayınlarla siyasete ve siyaset etme tarzına teorik ve felsefî düzeyde bir derinlik kazandırma amacı güdülmüşse de İttihat ve Terakki üzerinde bu tür düşüncelerin çok fazla etkisinin olmadığı daha sonraki uygulamalarda görülecektir.

Terakki gazetesi, ortaya koyduğu fikirler bakımından Jön Türk gazeteleri arasında seçkin bir yere sahip olup 1906'da Paris'te çıkmaya başlamış ve 1907 yılında da kapanmıştır. Gazete Prens Sabahattin tarafindan kurulan "Fenni İçtima ve Adem-i Merkeziyet Cemiyeti"nin yayın organı olarak çıkmıştır. Gazetenin amacı, fenni içtimaya dayanan teşebbüs-i şahsi fikrinin Osmanlı toplumunda yayılması ve halkın bu yönde uyandırılması olarak belirlenmiştir. ${ }^{42}$ Gazetede yer alan fikirler değerlendirildiğinde, genel olarak Osmanlı milletinin ilerleme kabiliyetine sahip olduğu fakat gerek siyasal sistem ve gerekse toplumsal yapıların bu ilerleme kabiliyetini engellediği yönünde olup bu durumdan kurtulmak içinde teşebbüs-i şahsi fikrinin insanlar arasında yayılmasını temin etmek suretiyle bireyselliğin geliştirilmesi önerilmektedir. ${ }^{43}$

\subsection{Ittihat ve Terakki'nin Yapısı, Sosyal ve Kurumsal Tabanı}

İttihat ve Terakki gerek yapısı ve gerekse sosyal ve kurumsal tabanı açısından Türk siyasal hayatının hala en tartışmalı konularından biri olmaya devam etmektedir. Çünkü İttihat ve Terakki, faaliyetlerine Osmanlı İmparatorluğu'nu düşmüş olduğu durumdan kurtarmak isteyen bir cemiyet olarak başlamasına rağmen 1908 ihtilali ile bir anda kendini ülkenin yönetiminde bulmuştur. Kuruluşundan itibaren siyasal bir harekete dönüşmeyi düşünmeyen İttihat ve Terakki'nin ülkenin siyasi yönetimine gelmesi önemli bir problemi de beraberinde getirmiştir. ${ }^{44} \mathrm{Bu}$ problem İttihat ve Terakki'nin parti ve cemiyet kimliklerinden hangisi ile tanımlanması gerektiği problemidir. Akşin'e göre bu cemiyet-fırka ikilemi İttihat ve Terakki tarafından hükümet işlerine müdahaleyi perdelemenin bir aracı olarak kullanılmıştır. ${ }^{45}$ Tunaya, İttihat ve Terakki içinde cemiyet

39 Ahmet Bedevi Kuran, Osmanlı İmparatorluğu’nda İnkılap Hareketleri ve Milli Mücadele, İstanbul (1956), 355.

40 Mardin, Jön Türkler'in Siyasî Fikirleri, 231.

41 Mardin, Jön Türkler'in Siyasî Fikirleri, 222.

42 Hidayet Uğur, “Jön Türkler'in Çıkardığı Gazeteler 3, Terakki” Türk Düşüncesi, Cilt: IV, Sayı:20, 1 Temmuz (1955), 72.

43 Uğur, "Jön Türkler’in Çıkardığı Gazeteler 3”, 74-80.

44 Tarık Zafer Tunaya, Türkiye'de Siyasal Partiler, Cilt: III, Itttihad ve Terakki Cemiyeti, Hürriyet Vakfı Yayınları, İstanbul (1989), 200.

45 Sina Akşin, "İttihad ve Terakki üzerine”, Ankara Üniversitesi SBF Dergisi, Sayı: 26, Ankara (1971), 
mensubiyetinin her zaman parti mensubiyetinden daha önemli olduğunu belirtmektedir. Çünkü firka cemiyetin doğurduğu çocuktu ve hem geçici hem de değişkendi. İttihat ve Terakki'ye yöneltilen eleştirilerden biri de gizliliğe yöneliktir. $\mathrm{Bu}$ eleştirilerin önü alınmak istenmiş ve bu amaçla 1908'deki kongrede cemiyetin gizlilikten çıktığı açıklanmış, ancak bu kongrede bile genel merkez üyelerinin adları gizli tutulmuştur. ${ }^{46}$

Toplumu yeniden dönüştürmeyi esas alan hareketlerin bir toplumsal tabana dayanmaları gerekir. Aksi takdirde başarılı olmaları zorlaşır. Tunçay’a göre İttihatçılar, 1908 Devrimi ile her ne kadar devleti sömürge olmaktan kurtarmak gibi bir amaçla yola çıkmış olsalar da içte dayanabilecekleri güçlü bir ekonomik tabanları olmadığı için yabancılara dayanmak zorunda kalmışlardır. ${ }^{47}$ İttihat ve Terakki'nin sosyal tabanı, Mardin'e göre, taşralı idi. ${ }^{48}$ Buna karşılık, İttihatçıların üyeleri arasında öğretmen, avukat gazeteci, doktor, küçük rütbeli subaylar ve memurlar ile esnaf ve tüccarlar yer almasına ve meşrutiyetin ilanına rağmen bu gelişmelerin bu kesimlere bir avantaj sağlamadığı ileri sürülmektedir. Bunun nedeni, İttihatçıların içinde bulundukları toplumsal yapıyı bozmadan statükoyu değiştirebilecekleri yanılgısından kaynaklanmaktadır. ${ }^{49}$ Bu düalist yapı İttihat ve Terakki'nin hem düşüncelerinde hem de uygulamalarında önemli bir kısıt olarak kendini göstermiştir. Osmanlılık fikri İttihatçılar için önemli bir argüman olmasına rağmen, İttihat ve Terakki Cemiyeti'nin üyelerinin neredeyse tamamının Müslümanlardan ve bilhassa da Türklerden oluşması Zürcher'e göre bir problem olarak tanımlanmaktadır. ${ }^{50}$ Kocahanoğlu, bu Türklere dayanma fikrînin Türklerin çıkarlarına hizmet ettiğini ancak teşkilatın bütün unsurlara açılabilmesi ve geniş kitleleri seferber edebilmesi için yeni bir ideolojiye ihtiyacı olduğunu ileri sürmektedir. Nihayet bütün unsurları işin içine katacak bu ideoloji, "İttihad-1 Anasır” veya "Osmanlılık” olarak formüle edilmiştir. ${ }^{51}$ İlginç bir şekilde İttihatçılar, çeşitli şikayetlere rağmen toprak ağaları ile ilgili bir mücadele içine girmemişlerdir. Çünkü 1858 Arazi Kanunnamesi ile bu grup sosyo-ekonomik anlamda önemli bir güç elde etmiş ve bu gücünü ilerleyen yıllarda daha da artırmıştır. Bu gücün farkında olan İttihatçılar, toprak sahibi bu kesimlerle bir güç mücadelesine girmemişlerdir. ${ }^{52}$ İttihat ve Terakki'nin toplumsal tabanı açısından askerlerin önemi büyüktür ve 1908 devrimine katılmalarında geciken maaş ödemelerinin yarattığı huzursuzluğun İttihat ve Terakki tarafından tahrik edilmesi etkili olmuştur. ${ }^{53}$ İttihat ve Terakki toplumsal taban açısından tanımlanması zor bir yapılanmadır. Bu nedenle ne tam olarak halka dayanmış ne de üst tabakaya dahil olup tepeden inmiş bir siyasi yapılanma olarak tanımlanamaz. ${ }^{54}$ Özetle İttihat ve Terakki tarafından gerçekleştirilen

156., Cemiyet-Fırka İkilemi için bkz: Ahmet Mehmet Efendioğlu, "İttihad ve Terakkinin 1909 Kongresi”, Toplumsal Tarih, Say1: 55, Temmuz (1998), 29.

46 Tunaya, Siyasal Partiler, Cilt: III, 200-201.

47 Mete Tunçay, Türkiye’de Sol Akımlar, 1908-1925, Bilgi Yayınevi, Ankara 2. Baskı (1967), 14.

48 Şerif Mardin, Siyasal ve Sosyal Bilimler, Makaleler 2, Mümtaz’er Türköne, Tuncay Önder (Haz.), İletişim Yayınları, İstanbul, 6. Baskı (2002), 143.

49 Ahmad, Itttihatçılıktan Kemalizm'e, 30.

50 Eric Jan Zürcher, Modernleşen Türkiye’nin Tarihi, İletişim Yayınları, İstanbul, 2.Baskı (1998), 142.

51 Osman Selim Kocahanoğlu, Ittihat ve Terakki’nin Sorgulanması ve Yargılanması, Temel Yayınları, İstanbul (1998), 18-19.

52 Ahmad, Ittihatçılıktan Kemalizm'e, 62-64., Akşin, 229-230.

53 Kansu, 97-111.

54 Niyazi Berkes, Türkiye’de Çağdaşlaşma, Ahmet Kuyas (Haz.), Yapı Kredi Yayınları, İstanbul, 3. Baskı, (2002), 402. 
1908 Devriminin geniş tabanlı bir toplumsal harekete dayanıp dayanmadığı konusunda yazarlar arasında bir görüş birliği yoktur. Ancak Kansu, 1908 Devrimi'nin birçok yazarın ifade ettiği gibi birkaç asker, şair, yazar ve bürokrat tarafından yapılmış olduğu görüşüne karşı çıkmakta ve bunun geniş toplum kesimlerine dayandığını iddia etmektedir. ${ }^{55}$

Osmanlı Devleti'nde özgürlükçü akımların ilk filizlendiği ve boy verdiği yer Tıbbiye Mektebi'dir. Bu durum ilk bakışta Mülkiye Mektebi’nin olduğu bir ülkede siyasal ve özgürlükçü akımların Mülkiye'de değil de Tıbbiye'de ortaya çıkmasını paradoksal bir durum gibi göstermektedir. Bu paradoksun ortadan kaldırılması için söz konusu okullardaki eğitim programları ve okutulan derslerin öğrencilerin zihnî süreçlerinde ne gibi etkiler ortaya koyduğuna bakılmasını gerektirmektedir. Hanioğlu'na göre, Tibbiye'de okutulan ve Fransa'dan getirilen ders kitaplarındaki pozitivist ve biyolojik materyalist düşünceler ve öğretmenlerin etkisiyle kendi değerler sistemi ile çatışan bir aydın tipi ortaya çıkmıştır. Diğer okulların ders içeriklerindeki temel farklılık nedeniyle böyle bir etki görülmemiş̧tir. ${ }^{56}$ Tıbbiye öğrencileri arasında özgürlük fikirlerinin ortaya çıkmasında Dr. Ferik Marko Apostol Paşa ile Sait Paşa'nın önemli etkileri olmuştur. ${ }^{57}$ Hanioğlu'na göre, Tıbbiyenin oluşturduğu aydın tipinin bir özelliği de sosyal olaylara kendilerince gerçek bilim olarak kabul ettikleri pozitif bilim yöntemlerini uygulamalarıdır. Bunun için önerdikleri yol, dinin yerini tamamen pozitivizmin önerdiği bilimsel yöntemlerin almasıydı. ${ }^{58}$ Tibbiye'de ortaya çıan muhalif hareketin bir nedeninin de öğrenciler arasındaki taşralı ve şehirli ayrımından kaynaklandığı görülmektedir. ${ }^{59}$

Osmanlı batılılaşma hareketlerinde Nizam-1 Cedit'ten bu tarafa ordunun ve askeri okulların önemi bilinen bir gerçektir. Harbiye Mektebi'nde memleketin kurtuluşu konusunda düşünen ve bir şeyler yapmayı tasarlayan gençlerin en yakın destekleyicilerinden biri olarak Fransızca öğretmeni Çürüksulu Ahmet Bey ve Muhittin Bey görülmektedir. Bu iki öğretmen, öğrencileri açıktan açığa Sultan Abdülhamit aleyhine tahrik etmekte ve komite kurmalarını teşvik etmekteydiler. ${ }^{60}$ Ayrıca, Jön Türk gruplarının özellikle harp okullarında ve sivil yüksek uzmanlık okullarında ortaya çıkması bir tesadüf değildir. Bu okulların gençlerin fikir ve düşünce dünyalarının gelişiminde çok önemli katkıları olmuştur. Çünkü gençler buralarda oldukça iyi bir eğitim görüyor, yabancı diller öğrenip çok az da olsa Avrupa devletlerinin ekonomik ve politik yaşamlarına ilişkin bilgi almak imkânını buluyorlard.$^{61}$ Jackh'a göre Harbiye öğrencilerinin ve Harbiye'den yetişen subayların İttihat ve Terakki'nin içinde yer almalarında, bütün eğitimleri boyunca Avrupalı düşünürleri tanımalarının yanında 1880'lerden itibaren tamamen Prusya ordusu reformcuları tarafından yetiştirilmelerinin de

55 Kansu, 153.

56 M. Şükrü Hanioğlu, Bir Siyasal Düşünür Olarak Doktor Abdullah Cevdet ve Dönemi, Üçdal Neşriyat, İstanbul, "t.y.", 8.

57 Süleyman Kani İrtem, Yıldız ve Jön Türkler, İttihat ve Terakki Cemiyeti Gizli Tarihi, Osman Selim Kocahanoğlu (Haz.), Temel Yayınları, İstanbul (1999), 11-12., Cemil Topuzlu, Istibdat-MeşrutiyetCumhuriyet Devirlerinde Seksen Yillı Hatıralarım, Hüsrev Hatemi ve Aykut Kazancigil (Haz.), İ.Ü.Cerrahpaşa Tıp Fakültesi Yayınları, İstanbul, 2. Baskı (1982), 16.

58 Hanioğlu, 13.

59 İbrahim Temo, Ittihad ve Terakki Cemiyeti’nin Teşekkülü ve Hidemat-ı Vataniye ve Inkılab-ı Milliye Dair Hatıratım, Mecidiye, Romanya, (1939), 11., Zikreden: Şerif Mardin, Jön Türkler’in Siyasî Fikirleri,.70.

60 Kuran, Inkllap Tarihimiz ve Jön Türkler, 50.

61 Petrosyan, 178. 
etkisi olmuştur. ${ }^{62}$

1859 yılında kurulan Mülkiye Mektebi Osmanlı Batılılaşma hareketini simgeleyen kurumların başında gelmektedir. Mülkiye'nin asıl önemi Osmanlı bürokrasisinin saray ve Enderun'da bir nevi usta-çırak ilişkisi şeklinde devletin bürokrat ihtiyacının karşılanması uygulamasından vazgeçilip Batılı anlamda bir eğitim sistemi ile yetiştirilmesinden kaynaklanmaktadır. Abdülhamit ile birlikte Mülkiye Mektebi'nin önemi artmış ve akademik yönü güçlenmiştir. ${ }^{63}$ Burada öğrencilerin ekonomik fikirlerinin gelişmesinde Portakal Paşa ile Sakız'lı Ohannes Efendi'nin önemi büyüktür. ${ }^{64}$ Çünkü ekonominin insan hayatı üzerindeki belirleyici etkisi ile ülkelerin ve milletlerin gücünün sahip oldukları emek ve mali yapıları ile ilgili olduğunu öğrenciler bu hocalardan öğrenmiştir. ${ }^{65} \mathrm{Bu}$ düşünceler, Mülkiye öğrencilerinde pozitivist bir tabiat anlayışıyla birlikte, toplumun ekonomik varlıkları ile emeğini esas alan realist bir toplum anlayışının gelişmesine katkısı olmuştur. ${ }^{66}$

\section{4.İttihat ve Terakki'nin İdeolojik ve Felsefi Yapısı}

Osmanlı modernleşme hareketi yönünü tamamen Batıya çevirmiş, bu nedenle de Batı medeniyeti ulaşılması gereken bir hedef olarak daima üstün konumunu muhafaza etmişstir. Osmanlı modernleşme hareketinde Batıyı algılama biçiminde daima bir problem teşkil eden medeniyet-kültür ilişkisi günümüzde bile devam eden bir tartışma ve çatışma zemininde hareket etmektedir. Jön Türkler modern Batı değerleri ile geleneksel değerler arasındaki çatışmayı gerek zihinlerinde ve gerekse uygulamalarında bir türlü terk edememişlerdir. Jön Türklerin birçoğunda pozitivist, materyalist ve Darvinist etkiler bariz bir şekilde görülmekle birlikte bunların yine birçoğunun Osmanlıcılık, İslamcılık ve Türkçülük fikirlerini de savunmaları geleneksel değerlerin etkisinden kurtulamadıklarını göstermektedir. Hatta 1908 Devrimine rağmen padişah otoritesini reddedememeleri de geleneksel değerler ile modern değerler çatışmasının en bariz örneğidir. Jön Türklerin siyasî ve felsefî düşüncelerinin şekillenmesinde uluslararası ilişkilere göre bir değişim olduğu gözlenmektedir. Ortaylı'ya göre, böyle bir tutum her hangi bir felsefî ya da siyasal düşüncenin uzun süreli ülke ve toplum gerçekleri karşısında test edilip derinleştirilmesini engellemiştir. Bu nedenle Jön Türklerin, 1912 Balkan bozgunundan sonra Almanya ile kurulan güzel ilişkiler sonucunda siyasî anlamda Pan-Türkizm'e ${ }^{67}$ ve Birinci Dünya Savaşı'nda da Alman millî iktisat düşüncesine doğru bir geçiş yaptıkları görülmektedir. ${ }^{68}$ Halbuki bundan önce Jön Türklerin Fransız ve İngiliz yanlısı oldukları siyasî anlamda meşrutiyeti ve iktisadî anlamda ise liberalizmi benimsedikleri bilinen bir gerçektir. ${ }^{69}$ Osmanlı' da batılılaşma çabaları genel bir zihniyet değişikliği getirmekle beraber içinden çıktıkları toplumun realitesinden uzak ve onunla çatışan bir sosyal ve kültürel ütopyanın peşine düşen bir seçkinler grubunu da ortaya çıkarmıştır. ${ }^{70}$ Sonuç olarak, pozitivizmden materyalizme, romantizmden ihtilalciliğe, liberalizmden sosyalizme,

\footnotetext{
62 Ernest Jackh, Yükselen Hilal, Bir Milletin Yeniden Doğuşu, Türklerin Dünü, Bugünü, Yarını, Çev. Perihan Kuturman, Temel Yayınları, İstanbul (1999), 127.

63 Mardin, Jön Türkler’in Siyasî Fikirleri, 47-48.

64 İrtem, Ylldız ve Jön Türkler, 16.

65 Ahmet İhsan, Matbuat Hatıralartm 1888-1923, I, İstanbul, 1930, 28-30.

66 Mardin, Jön Türklerin Siyasi Fikirleri, 49.

67 İlber Ortaylı, Osmanlı Imparatorluğunda Alman Nüfuzu, İletişim Yayınları, İstanbul (1998), 200-201.

68 Mardin, Siyasal ve Sosyal Bilimler, 108.

69 İrtem, Meşrutiyet Doğarken, 172-173.

70 Özbilgen, 90.
} 
millî iktisattan korporatizme, saltanattan meşrutiyete kadar birçok fikir ve sistem tartış1lmış, ancak hiçbirinde ciddi anlamda derinlikli bir fikir ortaya konulamamış, pragmatik ve eklektik bir yapının ötesine geçilememiştir.

\subsection{Birinci ve İkinci Jön Türk Kongreleri}

Fransa'da Prens Sabahattin'in gayretleri ile bütün Osmanlı özgürlükçü unsurlarını bir araya toplamayı amaçlayan I. Jön Türk Kongresi 4 Şubat 1902 tarihinde Ayan azasından Mösyö Leter Postalis'in evinde toplanmıştır. ${ }^{71}$ Petrosyan'a göre bu kongrenin önemi, Jön Türk hareketi ile Osmanlı Devletindeki gayri millî burjuvazinin ekonomik ve politik gücü arasındaki ilişkiyi göstermesidir. Sabahattin kongreyi açış konuşmasında, reform taleplerinin herhangi bir milletin dinin ve mezhebin yararına ya da zararına değil tüm Osmanlılar için olduğunu ifade etmiştir. ${ }^{72}$ Ancak bu düşünceler bir temenniyi yansıtmakla beraber gerçeklikten kopuk bir varsayıma dayanmaktadır. Bu varsayım, toplantıya katılan delegelerin sınırları içinde yaşadıkları Osmanlı Devleti'ne karşı tam bir bağlılık içinde oldukları varsayımıdır. Bu nedenle kongreden elle tutulur bir sonuç çıkmasını beklemek anlamlı değildi ve öyle de oldu. ${ }^{73}$ Buna rağmen Kongre'den iki önemli sonuç ortaya çıkmıştır. Bunlardan birincisi, yalnız propaganda ve yayın yoluyla inkılap yapılamayacağı ve bu nedenle askerî kuvvetlerin de ihtilal hareketine katılmaları, diğeri de ihtilalin gerçekleşebilmesi için yabancı hükümetlerin müdahalesinin sağlanması gerektiği fikridir. Bu tartışmalar sonunda İttihatçılar, müdahaleciler ve adem-i müdahaleciler olmak üzere ikiye ayrılmış ve Prens Sabahattin müdahaleci grupta, Ahmet Rıza Bey ise adem-i müdahaleci grupta yer almıştır. ${ }^{74}$ Kongrenin bir diğer önemli sonucu da İttihat ve Terakki'nin yabancıları iç işlerimize karışmaya çağırmak yolunu birakmalarıdır. $^{75}$

Birinci Jön Türk Kongresinden istenilen sonucun elde edilememesi üzerine Ermenilerin daveti ile İkinci Jön Türk Kongresi toplanmış ve bu toplantıya, Terakki ve İttihat Cemiyeti'nden Ahmet Rıza ve Sezai Bey, Teşebbüsü Şahsi ve Adem-i Merkeziyet Cemiyeti'nden Prens Sabahattin, Fazıl Bey ve Doktor Nihat Bey, Taşnaksütyon Partisi'nden parti başkanı Malumyan Efendi katılmıştır. ${ }^{76}$ Makedonya sosyalistleri İkinci Jön Türk Kongresine davet edilmelerine rağmen katılmamışlar ve katılmama gerekçelerini “Biz Makedonya'nın özerkliğini istiyoruz, Türkiye’yi diriltmeye çalışanlara katılmamız için bir neden yoktur. " şeklinde açıklamışlardır. ${ }^{77}$ 27-29 Aralık 1907 tarihinde Paris'te toplanan Kongrede, mevcut rejimin yıkılması, temsili bir yönetimin kurulması, bu amaçlara ulaşmak için barışçı ya da ihtilalci yolların araştırılması kararları alınmıştır. $\mathrm{Bu}$ amaçların gerçekleştirilebilmesi için de genel ayaklanma, hükümete karşı silahlı ve silahsız direnme, vergi ödememe yoluyla pasif direnme ve ordu içinde propaganda konuları tartışılmak üzere kongrenin onayına sunulmuştur. Bu yöntemlerden vergi ödememe yoluyla pasif direnişlerin Erzurum, Kastamonu ve diğer illerde uygulandığg görülmüştür. ${ }^{78}$ Petrosyan'a göre, bu kongrelerde

\footnotetext{
71 Kuran, Inkılap Hareketleri, 320.

72 Petrosyan, 216-217.

73 Ramsaur,.84, Kongreye katılanlar için bkz: İrtem, Yıldız ve Jön Türkler, 165.

74 Kuran, Inkllap Tarihimiz, 189-191.

75 Bayur, 17.

76 Petrosyan, 259, İrtem, Yıldız ve Jön Türkler, 245.

77 Fikret Adanır, "Osmanlı imparatorluğunda Ulusal Sorun İle Sosyalizmin Oluşması ve Gelişmesi: Makedonya Örneği”, Osmanlı Imparatorluğu’nda Sosyalizm ve Milliyetçilik 1876-1923, içinde, 56. 
alınan kararlar, Abdülhamit' in tahttan indirilmesi ile bütün problemlerin çözüleceği gibi tamamen ülkenin politik ve sosyal yaşamından kopuk ve yüzeysel bir bakış açısını yansıtmaktadır. Ancak bu eksikliğine rağmen bu kongreler, Jön Türk hareketini burjuva liberal bir hareketten burjuva devrimci bir harekete doğru evrilmesine neden olmuştur. ${ }^{79}$

\section{2.İttihat ve Terakki Dönemi İktisat Politikası Tartışmaları}

\subsection{Liberal İktisat Politikaları}

\subsubsection{Liberal İktisat Düşüncesinin Oluşumu ve Önemli Temsilcileri}

Osmanlı Devleti'nde liberal düşüncenin ithali batılılaşma çabaları ile ortaya çıkmaya başlamış ve özellikle yurtdışına öğrenci gönderilmesi ve yabancı daimi elçiliklerin kurulmasıyla önem kazanmıştır. 1789 Fransız İhtilali ile başlayan modern ulus-devlet süreci Osmanlı Devleti'ni de etkilemekte gecikmemiş, Askerî Tıbbiye, Harbiye ve Mülkiye Mekteplerindeki Batılı düşüncelerden etkilenmiş Türk aydınları ve yabancı hocalar kanalıyla bu süreç hızlanmıştır. Mardin'e göre Osmanlı Devleti'nde iktisat kültürünün eğitim müesseselerine girmesi Abdülhamit zamanında olmuştur. ${ }^{80}$ Fındıkoğlu, Osmanlı' da iktisat konusunda düşünenlerin ekonomik çöküşle ilgili görüşlerini Tanzimat öncesi ve sonrası olmak üzere iki noktada toplamaktadır. Tanzimat öncesi Osmanlı Devleti'nin ekonomik açıdan gerilemesinin nedeni kanunu kadimden ayrılışla açıklanırken, Tanzimat sonrası ise Avrupa karşısındaki teknik konularda geri kalışla açıklanmakta ve çözüm olarak Avrupa'nın fen ve fünununun Türkiye’ye nakledilmesi önerilmektedir. Bu dönemin iktisadî düşünce temsilcilerini "sanayiciler" ve "ziraatçılar" olarak ikiye ayırmak mümkündür. Birinci grup Türkiye'nin kurtuluşunu sanayileşmekte görürken, ikinci grup ise “serbesti-i mübadele”ye dayanarak Türkiye'nin bir ziraat memleketi olduğunu ve bu nedenle tarıma önem verilmesinin daha doğru olduğunu düşünmektedir. ${ }^{81}$ Türkiye' de liberal düşüncelerin oluşmasına önemli katkıları olan Sakız'lı Ohannes'e göre: “sanayiin ruhsatsız icra olunamaması yolunda ihdas olunan tahdidad esasen rekabete ve serbesti-i amale muhalif olmastyla ilmü servetçe külliyen muzır addedilir', ${ }^{82}$ Görüleceği üzere bu ifadeler liberal iktisadın ticaret serbestisi kavramı ile bire bir uyumludur. Osmanlı Devleti'nde liberal düşüncelerin benimsenmesinde, yabancı uzmanların, devlet adamları ve üst düzey bürokratlara ticaret ve sanayinin önündeki engellerin kaldırılması yolundaki tavsiyeleri ile gazete ve dergilerin önemli bir yeri olmuştur. Bu gazetelerin başında Takvim-i Vekayi gelmektedir. Bu gazetenin sütunlarında "ticaret ve es 'ar " başlığı altında çoğu İngiliz gazetelerinden aktarılan iktisat konusuna dair makaleler çıkmıştır. Ceride-i Havadis gazetesinin 1830 ve 1840 yıllarına ait sayılarında da Osmanlı'da tartışılan iktisadî meselelerin takibi mümkündür. Churchill bu gazetedeki yazılarında liberal iktisatçıların mukayeseli üstünlükler teorisine uygun olarak Osmanlıların her şeyden önce ham madde ihracına gitmeleri lazım geldiği tezini ileri sürmektedir. Tercüman-1 Ahvâl'de de Şerif Efendi endüstrileşme tezini savunmaktaydı. Ancak Türkiye'deki endüstrileşme teşebbüslerinin başarısız kalması üzerine, işe endüstrileşmeden başlanamayacağı düşüncesi ağır basmaya başlamış ve bu durum serbest ticaret fikrinin benimsenmesine neden olmuştur. Bundan dolayıdır ki Türkçeye tercüme edilen ilk iktisat kitabı

79 Petrosyan, 267.

80 Mardin, Siyasal ve Sosyal Bilimler, 94.

81 Ziyaeddin Fahri Fındıkoğlu, Türkiye’de İktisat Tedrisatı Tarihçesi ve İktisat Fakültesi Teşkilatı, İsmail Akgün Matbaası, İstanbul (1946), 41-42.

82 Findikoğlu, 44-45. 
J.B. Say'in Catechisme d'Economie Politique'i olmuş ve bu eser Türkiye'de iktisadî düşüncenin gelişimine önemli katkı sağlamıştır. ${ }^{83} 1908$ Devriminden sonra İttihatçılar ekonomik sistem tercihi açısından iki seçenekle karşı karşıya kalmışlardır. Bu seçeneklerden biri Prens Sabahattin'in şahsi teşebbüs fikri ile devletin merkezileşmeden uzaklaşması, diğeri Cavid Bey ve yandaşlarının klasik iktisatçıların düşüncelerine uygun olarak önerdikleri devletin ekonomiye müdahale etmemesi ve serbest ticaret düşüncesidir. ${ }^{84}$

Liberal düşüncelerin oluşmasında ve ekonomi alanındaki bilgi birikiminin zenginleşmesinde, Ulum-1 îktisadiyye ve İctimaiyye Mecmuası'nın önemli katkıları olmuştur. Derginin birinci sayısında "Mukaddime ve Program" başlığı altında Avrupa'daki iktisadî gelişmelerin takip edileceği ve bu gelişmelerle ilgili olarak yeri geldikçe halkı aydınlatıcı bilgiler verileceği ifade edilmektedir. ${ }^{85}$ İttihat ve Terakki'nin liberal kanadında yer alan Mehmet Cavid Bey, derginin kurucuları ve yazarları arasındadır. Osmanlı Devleti'nde liberal düşünceyi benimseyenler genellikle zengin ve tutucu ailelere mensupturlar. Bunun yanında liberaller, etnik gruplara özerklik verilmesi fikrinde olduklarından İmparatorluğun Türk olmayan nüfusu ${ }^{86}$ ile İttihatçıların ekonomik milliyetçiliği yüzünden kendilerini tehdit altında hisseden gruplar ve devletler tarafından da desteklenmişlerdir. ${ }^{87}$

İttihat ve Terakki içinde liberal düşüncenin en önemli temsilcisi kuşkusuz ki Cavid Bey'dir. Cavid Bey'e göre hükümetler her şeyden önce aldatıcı bir politika olan usul-ü himayeyi terk etmelidirler. Çünkü himayecilerin savunduklarının tersine koruyucu bir dış ticaret politikasıyla ülkede fabrikalar kurulabilse bile bunun zenginliğin tabana yayılmasından ziyade ancak belli kişilerin zengin olmasına katkısı olacaktır. Bu nedenle Cavid Bey, ekonomik gelişme için öncelikli olarak tarım ve ticarete ağırlık verilmesini önermekte, bunlar geliştikçe de sanayinin buna paralel olarak gelişeceğini ileri sürmektedir. ${ }^{88}$ Cavid Bey, ekonomik gelişme için yabancı sermaye ile eksik olan yönetim tecrübesinin transferinin önemine inanmış ve bunun için Japon hükümetine başvurarak kendilerine uzman gönderilmesini talep etmiştir. ${ }^{89}$ Cavid Bey yabancı sermayeden yana olan tavrı nedeniyle Osmanlıların yarı sömürge oluşunu simgeleyen kurumların karşısında olmamış ve Düyun-u Umumiye ile Osmanlı Bankası'nı çok iyi çalışan ve örnek alınması gereken ekonomik kurumlar olarak tanımlamıştır. ${ }^{90}$ Cavid Bey'e göre toplumsal refaha ulaşmanın anahtarı kişisel çıkar kavramıdır. Bu nedenle bireyciliği toplumculuktan üstün görmüş ve kişisel özgürlüğü toplumun özgürlüğüne feda eden sosyalizme karşı olmuş ${ }^{91}$ ve hürriyet kavramını iktisadî gelişmenin olmazsa olmaz koşulu olarak kabul etmiştir..$^{92}$

83 Mardin, Siyasal ve Sosyal Bilimler, 73-75.

84 Zafer Toprak, Türkiye'de Milli İktisat 1908-1918, Yurt Yayınları, Ankara (1982), 18.

85 Ahmed Şuayb, Mehmed Câvid ve Rizâ Tevfik "Mukaddime ve Program", Ulûm-ı İktisâdiyye ve İctimâ'iyye Mecmuasl, C.I, Say1 1,15 K.evvel 1324, 1-10.

86 Ahmad, Itttihatçıllktan Kemalizm'e, 10.

87 Ahmad, Ittihatçılıktan Kemalizm'e, 24.

88 Toprak, Milli İktisat, 107-108.

89 Zürcher, Modernleşen Türkiye'nin Tarihi, 180.

90 Tevfik Çavdar, Ittihad ve Terakki, İletişim Yayınları, İstanbul (1991), 98.

91 Toprak, Milli Iktisat, 123.

92 Deniz Karaman, Cavit Bey ve Ulum-ı İktisadiye ve İçtimaiye Mecmuası, Liberte Yayınları, Ankara (2001), 14. 


\subsubsection{Liberal İktisat Politikası Önerileri}

İttihat ve Terakki döneminde liberal düşünceyi temsil edenler tam anlamıyla klasik iktisadın temel varsayımlarından hareket etmişler ve bu varsayımları mutlak doğru olarak kabul etmişlerdir. Bu nedenle ülkenin kalkınmasını "mutlak üstünlükler teorisi" çerçevesinde değerlendirmişler ve tarım kesiminde görmüşlerdir. Cavid Bey’e göre "sanat sanat içindir" fikrî iktisadî alanda geçerli değildir. Dolayısıyla üretmiş olmak için üretilmez. Böyle olduğu için dışarıdan uygun fiyatlarla elde edilebilecek malların içeride pahalıya üretilmesi mesailerin ve sermayelerin heder olmasına yol açar. Bu düşünceler 1şığında, Osmanlı ülkesi bir ziraat ülkesi olduğundan büyük sanayinin kurulması için harcanacak zaman ve sermayenin yanında vasıflı iş gücünün de eksik olması nedeniyle daha yüksek fiyatlarla üretilecek bir malın ne üretici, ne de tüketici için herhangi bir faydası olmayacaktır. ${ }^{93} \mathrm{Bu}$ düşüncelerini, Ulum-ı İktisadiye ve İçtimaiye Mecmuası'nda "Mukaddime ve Program' başlıklı yazılarında "memleketimizin bir ziraat memleketi olduğundan hareketle tarımın sanayiye tercih edilmesi gerektiği”" ${ }^{44}$ şeklinde belirtmektedirler. Ahmed Muhtar, "Ziraî Program” adlı makalesinde, Osmanlı Devleti'nin bir ziraat memleketi olduğunu ve yüzyılımızda iktisadî rekabetlerin çok fazla arttığını, bu nedenle de her ülkenin çabalarını en güçlü olduğu alanlara hasretmeleri gerektiğini belirterek, Osmanlı Devleti'nin çabalarını tarımsal faaliyetlere yoğunlaştırmasını önermektedir. ${ }^{95}$ Özetle, liberallerin tarım politikaları klasik iktisadın "mutlak üstünlükler teorisi” kapsamında değerlendirilmektedir.

Liberaller ticaret politikaları açısından serbest ticaretten yana olmuşlardır. Cavid Bey’e göre, iktisadî hayatın ruhu ticarettir ve tarım ve sanayinin gelişmesi ancak ticaretteki gelişmeyle birlikte olması halinde ülkenin gelişmesine katkı yapabilir. Bu nedenle anonim şirketlerin gelişmesi ülkeler açısından iktisadî menfaatler yanında uluslararası alanda siyasî menfaatler temin edilmesine de katkı sunabilir. ${ }^{96}$ Cavid Bey ticaret odaları ile ilgili bir makalesinde, Amerika'nın yakın zamanlara kadar satmaktan ziyade üretmeye yönelik politikalardan vazgeçtiğini, bazı ülkelerle ticaret anlaşmaları yaparak gümrük vergilerinin kaldırıldığını ve bunun diğer ülkeler içinde örnek olması gerektiğini belirtmektedir. ${ }^{97} \mathrm{Bu}$ ifadelerden de anlaşılacağı üzere çeşitli gümrük anlaşmaları ile ticaretin önündeki engellerin kaldırılması ve ülkeler arasındaki ticaretin serbest rekabet kavramına uygun olarak yapılması önerilmektedir.

İttihatçıların liberal kanadının sanayileşme konusundaki yaklaşımları çok olumlu değildir. Bu yaklaşımlarını, Ulum-1 İktisadiye ve İçtimaiye Mecmuası'nda şu şekilde ifade etmişlerdir. "Ülkemizde de sanayi tesislerinin kurulmasını istemekle beraber bir hayal peşinde koşmayacă̆ız. Ancak hammaddesi ülkemizde yetişen malların üretimi ile ilgili tesisler kurulmasında bir sakınca olmamakla beraber, çok daha büyük sanayi tesislerinin kurulması gibi bir düşünce peşinde koşarak hem halkımızı kandırmaktan hem de hazineyi gereksiz masraflara sokmaktan kaçınacağız ve bu tür teşebbüslerin aleyhinde olacă̆ız". ${ }^{98}$ Cavid Bey'e göre, ekonomik açıdan en güçlü devletler bir malın üretiminde en iyi olan devletlerdir. Bu açıdan bakıldığında, Türkiye tarım ülkesi

93 Karaman, 16.

94 Ahmed Şuayb, Mehmed Câvid ve Rıâ Tevfik, 4.

95 Ahmed Muhtar, "Zirâi Program”, Ulum-ı İktisâdiye ve İctimaiyye Mecmuası, C.II, Sayı 9, 1 Eylül 1325, 51-70.

96 Karaman,26-35.

97 Mehmed Cavid, "Ticaret Odaları” Ulum-ı İktisadiye ve İçtimaiye Mecmuası, Cilt:I, Sayı: 2, Yıl:1, 200.

98 Ahmed Şuayb, Mehmed Câvid ve Rızâ Tevfik, 4. 
olduğundan bu alanda uzmanlaşmalı ve bütün enerjisini bu alana yöneltmelidir. ${ }^{99}$ Liberal kanadın önemli temsilcilerinden Ahmed Muhtar da, "Osmanlı Devleti'nin bir ziraat memleketi olduğunu bir sanayi memleketi olmadı̆̆ını ve uzun bir süre de olmayacağını belirtmektedir". ${ }^{100}$ Görüleceği üzere liberaller, sanayileşme politikalarına temkinli yaklaşmakta ve "mutlak üstünlükler" kavramı gereği Osmanlı kalkınmasını tarımsal alandaki gelişmelere dayandırmaktadırlar.

Batı karşısında sürekli gerileyen ve bu nedenle de Batı'nın açık pazarı haline gelen Osmanlı Devleti'nde, maliye alanında yapılacak çalışmalar önemli bir öncelik olarak görülmektedir. $\mathrm{Bu}$ nedenle İttihat ve Terakki içinde böyle bir görevi yerine getirebilecek kişi olarak Cavid Bey'in ismi ön plana çıkmış olmasına rağmen maliye politikalarının ne olacağı konusunda bir görüş birliği sağlanamamıştır. Uzlaşma sağlanamamasının nedenlerinden biri savunma bütçesinin ne olacağ 1 diğeri de Harbiye Nezaretinin Divan-1 Muhasebat denetimine tabi olmamasıdır. ${ }^{101}$ Liberaller, Osmanlı Devleti'nde bütçe ve vergileme konusunda belirlenmiş herhangi bir politikanın olmadığını eleştirmekte ve bütçenin adaletli bir şekilde dağıtılması ve harcamaların kontrol edilmesini önermektedirler. Faik Nüzhet, a'şâr vergisinin bütçe için önemini belirtmekte ve bu nedenle bu vergi kalemi ile oynanmasını sakıncalı görmektedir. Ancak, a'şâr usulünün çok çalışanı daha çok ve az çalışanı daha az vergilendirmek suretiyle cezalandıran bir vergi olduğu için çiftliklerin boş kalmasına ve çiftçileri de tembelliğe sevk ettiği için eleştirmektedir. Bu olumsuzlukları gidermek için de her ürün için aynı vergi oranı belirlemek yerine farklı ürünler için farklı oranların belirlenmesini önermektedir. ${ }^{102}$ Faik Nüzhet, temettü vergisini de imtiyazlı şirket çalışanları ile diğer şirket çalışanları arasında farklı oranlarda uygulandığ 1 için eleştirmekte ve Avrupa'daki uygulamaların esas alınması gereğine işaret etmektedir. ${ }^{103}$ Zühdi, "verginin yansitılması" nın sermaye birikimine katkısı olacağını kabul etmekle beraber yansıtılan vergilerin sabit ücretliler ile köylüler üzerinde bir yük oluşturacağı için bu politikanın uygulanması konusunda çok dikkatli olunmasını ve vergi yükünün doğru hesaplanmasını önermektedir. ${ }^{104}$ Sonuç olarak ifade etmek gerekirse liberallerin maliye politikası önerileri, vergilerin gelirlerle doğru orantılı olması ve toplumsal dengeyi bozmaması esasına dayanmakta ve devletin maliye ve para politikalarına klasik iktisadın "görünmez el kavramı " nedeniyle müdahale etmemesi esasına dayanmaktadır.

İttihatçıların liberal kanadının yabancı sermayeye karşı olmadıkları bilinmektedir. Cavid Bey borçlanmanın, kişileriçin olduğugibi devletleriçinde gelirlerin giderlerikarşılayamaması durumunda ortaya çıktığını ve yalnızca fakir ülkeler için değil gelişmiş ülkelerde bile olabildiğini söylemekte, ancak borçlanmada bütçe dengesine dikkat edilmesi gereğine işaret etmektedir. Borçlanmaların genellikle, alt yapı, savaş, askeri teçhizat ve silah gibi harcamalar için zorunlu olduğunu, çünkü ilgili yıl gelirleri ile bu giderlerin karşılanmasının mümkün olmadığını belirtmektedir. ${ }^{105}$ Liberaller,

\footnotetext{
99 Toprak, Milli Iktisat, 109.

100 Ahmed Muhtar, 49-50.

101 Akşin, Jön Türkler ve İttihad Terakki, 248-49.

102 Faik Nüzhet, "A'şâr", Ulûm-ı İktisâdiye ve İçtimaiyye Mecmuası, Yıl: 1, Cilt: III, Sayı: 12, 440- 442.

103 Faik Nüzhet, "Temettü Vergisi”, Ulûm-ı İktisâdiye ve İ̧̧timaiyye Mecmuası, Yıl: 1, Cilt:1, Sayı: 3, 289314.

104 Zühdî, “İn'ikas-1 Tekalif”, Ulûm-ı İktisâdiye ve İçtimâiyye Mecmuası, Yı1: 3, Sayı: 26, 1349- 1362.

105 Mehmed Cavid, "İstikrazat", Ulûm-ı İktisâdiye ve İçtimâiyye Mecmuası, Cilt: 3, Sayı: 10, Y11 1, $257-$ 258., Mehmed Cavid'in Borçlanma ile ilgili düşünceleri için bkz.: Mehmed Cavid, "İstikrâzât", Ulûm-ı İktisâdiye ve İçtimâiyye Mecmuası, Cilt: 3, Say1: 11, Yıl 1, 386-426; Mehmed Cavid, "İstikrâzât", Ulûm-ı İktisâdiye ve İçtimâiyye Mecmuası, Cilt: 3, Sayı: 12, Yıl 1, 513-554.
} 
yabancı sermayenin gerekliliğine her ülkenin aynı gelişmişlik düzeyinde olmadığı argümanı ile cevap vermekte ve yukarıda sayılan yatırımlar için yabancı sermayeye ihtiyaç duyulduğunu kabul etmektedirler. Cavid Bey' in tabiri ile "yabancı sermayeye müracaat etmemek vesait-i medeniyeden mahrumiyettir". ${ }^{106}$

\subsubsection{Liberal İktisat Politikalarına Yönelik Eleştiriler}

Millî iktisatçılarla liberallerin ekonominin işleyişine yönelik yaklaşımlarındaki temel fark ilkesel bir farktan kaynaklanmaktadır. Genel olarak List' in görüşlerinden etkilenen millî iktisatçılar ekonominin geliştirilebilmesi için gelişme döneminde koruyucu ve teşvik edici bir takım araçlarla desteklenmesini önerirken, liberaller ekonomiye hiçbir şekilde müdahale edilmemesi gerektiğini düşünmektedirler. $\mathrm{Bu}$ nedenle milli iktisatç1lar, liberallerin, serbest rekabet ve serbest ticaret yaklaşımlarını, zaten yarı sömürge durumundaki bir ülkenin kalkınmasını güçleştiren en önemli problem olarak görmektedirler. Tekinalp bu gerekçelerle liberallere karşı çıkmakta ve İttihatçılar tarafından önerilen devletçiliğin, özel sektörün önünü kesmek gibi bir düşüncesinin olmadığını, tam tersine müteşebbislere yol göstermek ve faaliyet gösterebilecekleri uygun bir ekonomik ortam hazırlamak olduğunu ifade etmektedir. $\mathrm{Bu}$ düşüncelerden hareketle Türkiye'ye model olarak Almanya'nın savaş dönemi ekonomisini önermekte ve liberal iktisadın karşısında olduğunu belirtmektedir. ${ }^{107}$ Millî iktisat düşüncesi taraftarları Cavid Bey’in liberal dış politikalarına karşı eleştirilerini, Osmanlı Ticaret ve Ziraat gazetesinde "Cavid Beyefendi, bila kaydu şart serbesti-i ticareti iltizam buyuruyorsa da biz bu fikirde değiliz" cümleleriyle dile getirmişlerdir. Milli iktisatçılar, serbest ticarete karşı, 1lımlı bir koruyucu gümrük politikası ile bazı mallarda serbest ticaretin, bazı mallarda ise usul-ü himayenin tatbik edilmesini öneriyorlardı. Milli iktisatçılara göre, liberallerin mutlak üstünlükler teorisinin kabul edilmesi halinde, Türkiye bugün olduğu gibi yarın da ziraat memleketi olarak kalacak ve hiçbir zaman sanayileşmesi mümkün olmayacaktır. ${ }^{108}$ $\mathrm{Bu}$ eleştirilerden de anlaşılacağı üzere millî iktisatçıların liberallere yönelttiği eleştirilen temelinde Friedrich List tarafından geliştirilen Alman modelinin esas alındığı koruyucu bir ticaret politikasından hareket edildiği görülmektedir.

Sosyalistlerin liberallere yönelik eleştirilerini dile getiren Zöhrap Efendi, Cavid Bey’in serbest dış ticaret politikasının ülke çıkarları ve iktisadî bağımsızlıkla bağdaşmadığını ve bu nedenle Osmanlı Devleti için makul bir korumacılık politikasının yararlı olacağını ileri sürmektedir. ${ }^{109}$ Mustafa Suphi liberallerin "Teşebbüs-i şahsi” görüşünü eleştirmekte ve toplumdaki küçük sermaye sahiplerinin tasarruflarını "teşebbüs-i şahsi" adına işletmelerinin toplumsal dengeyi bozacağını ancak çalışanların ve küçük üreticilerin “teşebbüs-i içtima-i”leri ile oluşturacakları kooperatifler yoluyla servet ve gelir bölüşümünden doğacak çarpıklıkların giderilebileceğini öne sürmektedir. Dengeli bir toplumsal düzen içinde, üretim, tüketim ve kredi kooperatiflerinin kurulmasını önermektedir. ${ }^{110}$ Sosyalistlerin liberallere yönelik eleştirileri sermaye ve bölüşüm kavramlarından hareketle toplumsal denge üzerine yoğunlaşmaktadır.

106 Mehmed Cavid, “Ecnebi Sermayeleri 2”, Sabah, 15 Teşrin-i Evvel 1908, s. 1, Zikreden: Karaman, 17.

107 Tekin Alp, "Harpten Sulha Intikat Iktisadiyatı-Devlet İktisadiyatı", İktisadiyat Mecmuası, Cilt: 2, Sayı: 62-64, 16 Ağustos ve 14 Eylül 1917, s. 1-3, zikreden: Ahmad, s.60.

108 "Muhasebei- İktisadiyye: Serbesti-i Ticaret ve Usul-u Himaye", Osmanlı Ziraat ve Ticaret Gazetesi, 3. Sene, No: 1, 13 Mart 1325, s.14-16, zikreden: Toprak, 110.

109 Toprak, Milli Iktisat, 112.

110 Toprak, Milli Ikktisat, 215-16. 


\subsection{Milli İktisat Politikaları}

\subsubsection{Milli İktisat Düşüncesinin Oluşumu ve Önemli Temsilcileri}

Osmanlı Devleti bilindiği üzere bir milletler topluluğundan oluşmaktaydı ve bu yapısını devam ettirilebileceği düşüncesini son zamanlara kadar da muhafaza etmiştir. Shaw’a göre Arnavut isyanı, Osmanlılara bu politikanın devam ettirilme şansının kalmadığını göstermiş ve bu durum bir kısım insanları İslamcılığa bir kısmını da Türk milliyetçiliği fikrine yöneltmiştir. ${ }^{11}$ Osmanlı'da Türkçülük akımının gelişmesinde I. Dünya Savaşı, Patrikhane ve bazı azınlık millî kulüplerinin kendi ulusal çıkarlarının peşine düşmelerine karşı duyulan tepkide önemli olmuş ve bu tepki daha sonra, İttihatçılar tarafından devletin siyasi, ekonomik ve kültürel meselelerini millî değerlere ve "millet bilinci"ne yönlendirme çabalarına yardımcı olmuştur. ${ }^{12}$ Bunların yanında, Trablusgarp ve Balkan Savaşlarındaki büyük toprak kayıpları, buralardan Anadolu ve Trakya'ya olan göçler ve ekonomik bunalımın yarattığı tepkilerde milliyetçi fikirlerin gelişmesine zemin hazırlamıştır. Yabancı mallara karşı başlatılan boykotlar, yerli malı kullanımının teşvik edilmesi, millî burjuva yetiştirme çabaları yukarıda sayılan problemlere karşı oluşan tepkilerin işaretleridir. ${ }^{113}$ Milliyetçilik fikirlerinin 1908 Devrimi ile ortaya çıkan iktisadî liberalizme bir tepkinin sonucu olarak görenler 114 olduğu gibi bunu Alman Doğu bilimcilerinden Ernest Jaeckh'in etkilerine bağlayanlarda olmuştur. ${ }^{115}$ Türkçülük'ün yayılmasında dergilerinde önemli bir etkisi olmuştur. Bu dergiler arasında, Türk Ocağı'nın yayın organı olan Türk Yurdu, Selanik’te yayınlanan Genç Kalemler ve İstanbul'da yayınlanan Yeni Mecmua'yı saymak gerekir. ${ }^{116} \mathrm{Bu}$ dönemde milliyetçiliğin ve iktisadî Türkçülüğün yayılmasında, Kazanlı Musa Akyiğit, Parvus takma adlı bir Rus Yahudisi olan Alexander Helphand, Ziya Gökalp, Tekin Alp gibi kişiler göze çarpmaktadır. ${ }^{117}$

Osmanlı Devleti'nde yayılan milliyetçilik akımının ekonomik düzlemde yansıması, mili iktisat düşüncesinde görülmektedir. Parvus, Türkiye'nin Kırım Savaşı'ndan beri Avrupa maliyecilerinin elinde inlediğini, bundan önce rahat bir şekilde yaşayan Türk köylüsünün artık tam bir sefalet içinde olduğunu ve bundan kurtulabilmek için millî istihsal ve servet yollarının bulunması gereğini dile getirmektedir. Ancak bu yolla Avrupa maliyecilerinin ve imtiyazlı yabacı şirketlerin pençesinden kurtularak bir Türk iktisadiyatını kurmanın mümkün olacağını belirtmektedir. ${ }^{118} \mathrm{Bu}$ düşüncelerin etkisiyle İttihat ve Terakki Cemiyeti ilk defa 1913 Kongresi'nde "Ittihat ve Terakki Fırkası mili iktisat siyasetinin bă̆ımsızlı̆̆ını zorlaştıran ve yabancılarla ilgili malî ve iktisadî imtiyaz ve

111 Standford Shaw, Ezel Kural. Osmanlı Imparatorluğu ve Modern Türkiye, , Reform, Devrim, Cumhuriyet; Modern Türkiye’nin Doğuşu 1808-1975, Çev. Mehmet Harmancı, Cilt :2, E Yayınları, İstanbul, 3. Bask1 (2000), 348., Bayur, 92-94., Ayrıntılı bilgi için bkz: Mustafa E. Elöve, "Umumi Amme Hukukumuz Bakımından 2. Meşrutiyet Devrinin Türkçülük Cereyanı” Ankara Üniversitesi SBF Dergisi, Cilt:7, Sayı: 1-4, (1952), 218-260.

112 Kocahanoğlu, Itttihad ve Terakki’nin Sorgulanması, 20-21., Peyami Safa, Türk Inkılabına Bakışlar, Ötüken Neşriyat A.Ş, İstanbul, 2. Bask1 (1990), 74-75.

113 Gülten Kazgan, Tanzimat'tan 21. Yüzyıla Türkiye Ekonomisi, İstanbul Bilgi Üniversitesi Yayınları, 3940.

114 Toprak, Milli İktisat, 20.

115 Ortayl1, 201-202., Toprak, 28-2.9., Petrosyan, 292-293.

116 David Kushner, Türk Milliyetçiliği’nin Doğuşu (1876-1908), Çev. Şevket Serdar Türet, Rekin Ertem ve Fahri Erdem, Kervan Yayınları, İstanbul (1979), 154.

117 Akşin, 395-97.

118 Peyami Safa, 55-56. 
ayrılıkları kaldırmaya çalışacağı gibi tüm kapitülasyonların da kaldırılmasını sağlamayı en kutsal amaç sayar" "119 ifadeleri ile milli iktisat politikalarını benimsediğini açıklamıştır. Ahmet Muhiddin, İslam Mecmuası'nda millî iktisat anlayışının devletle halkın el ele vermesiyle tesis edilebileceğini belirtmekte ve Türklerin iktisaden geri kalmalarını bir orta sınıfın, yani burjuvanın olmayışına bağlamaktadır. Bunun yanında yabancı sermayeyi tehlikeli görmekte, bunun için bir taraftan millî sermayenin oluşturulmasını diğer taraftan da millî emeği idare edecek teşkilatlar kurarak üretimin artırılmasını gerekli görmektedir. ${ }^{120}$ Özetle, Osmanlı Devleti’nde milliyetçilik akımları ile birlikte millî iktisat düşüncesi de gelişmeye başlamış ve yeni bir toplum tasarımında ekonominin önemi kavranmıştır. Bu konuda model olarak İttihatçıların Almanya ile kurmuş olduğu yakın ilişkiler nedeniyle milliyetçi iktisat ekolünün ${ }^{121}$ benimsendiği görülmektedir.

İttihat ve Terakki döneminde milliyetçilik ve milli iktisat düşüncesinin şekillenmesinde Ziya Gökalp'in yeri önemlidir. Zürcher'e göre Gökalp, kültür ve medeniyet arasında ayrım yapmış ve bu ayrımdan hareketle toplumun gelişmesi için Türk kültürünü koruyarak onun yerine modern Avrupa uygarlığını geçirmeyi öneren bir senteze ulaşmıştır. ${ }^{122}$ Gökalp'e göre, Avrupa medeniyetinin ve o medeniyeti ortaya çıkaran müspet bilimler, sınaî teknikler ve içtimaî teşkilatların alınması bir zarurettir. Bu medeniyet transferinde, müspet ilimlerin oralardaki sonuçlarının alınmasından ziyade bu ilimlerin ve usullerin alınacağını, hatta tekniklerin ve fenlerin ürünlerinin değil, kendilerinin alınacağını ifade etmektedir. ${ }^{123}$ Gökalp, batının gelişmesini kapitalizmin sanayi ve teknoloji alanındaki başarısına ve bunu mümkün kılan pozitif bilimlere bağlamaktadır. ${ }^{124}$ Ziya Gökalp bir ideal olarak batılılaşma ve dolayısıyla Batı medeniyetinin alınmasını bir zorunluluk olarak kabul etmekle birlikte, liberal ve sosyalist fikirlere karşıdır. Gökalp, sınıflar arası çatışma kavramından dolayı sosyalizmin, Türk milletinin kalkınma sorununa katkısı olamayacağını ileri sürmektedir. ${ }^{125}$ Buna karşı1ık Gökalp, feodalitenin yıkılması açısından bir burjuva sınıfının gerekli olduğu düşüncesini

119 Çavdar, 90

120 Âhmed Muhiddin, "Milli Sermaye-Milli Sermaye Teşkilatı”, İslam Mecmuası, Cilt: 3, Sayı: 33, 29 Temmuz, 1331, s. 10, Zikreden: Yıldız Akpolat-Davut, "İkinci Meşrutiyet Dönemi Sosyolojisinin Kaynakları II: İslam Mecmuası ”, Türkiye Günlüğ̈̈, Sayı:45, Mart-Nisan 1997, 214-15.

121 Toprak, s.25-vd, Bu ekolün doktrin tarihindeki yeri ve temsilcileri ile ilgili olarak bkz:Tevfik Ertüzün, “Milliyetçi İktisat Ekolü” Türk Dünyası Araştırmaları (Prof. Dr. Mehmet Eröz'e Armăgan), Sayı:48, Haziran (1987), 163-74.

122 Zürcher, s.91-92, Ziya Gökalp ile ilgili değerlendirmeler için bkz: İsmail Hakkı Baltacıŏlu, "Ziya Gökalp”, Sosyoloji Konferanslarl, 5. Kitap, 1964-1965 Ders Yllı, İstanbul, 1-7; Ayşenur Öktem, "Yerli ve Yabancı Ansiklopedilerde Ziya Gökalp” 1976 Yılı Sosyoloji Konferansları (Ziya Gökalp Özel Sayısı), 14. Kitap, İstanbul, 119-139, Orhan Türkdoğan, “Ziya Gökalp’te Çağdaşlaşma, İslamlaşma, Türkleşme Akımları ve Millî Devlet Fikrinin Gelişimi”, İstanbul Üniversitesi İktisat Fakültesi Mecmuası, Cilt:36,Say1: 1-4, (1976-1977); Korkut Tuna, “Gökalp’in Millî Sosyoloji Anlayışı” İstanbul Üniversitesi İktisat Fakültesi Metodoloji ve Sosyoloji Araştırmaları Merkezi, Sosyoloji Konferanslarl, 21. Kitap, İstanbul (1986), 51-67; Cavit Orhan Tütengil, “Ziya Gökalp Üzerine Notlar”, İstanbul Üniversitesi Edebiyat Fakültesi Yayınlarl, Sosyoloji Dergisi, Sayı: 10-11, (1955-1956), 101-105; Akçuraoğlu Yusuf, “Gökalp Ziya Bey hakkında Hatıra ve Mülahazalar”, Mehmet Özden (Sad.), Türkiye Günlüğü, Sayı:20, Güz (1992), 79-81.

123 Ziya Gökalp, İnkılapçılık ve Muhafazakarlık, Makaleler IX, Şevket Beysanoğlu (Haz.), Kültür Bakanlığ1 Yayınları, İstanbul (1980), 40-42.

124 Taha Parla, Ziya Gökalp, Kemalizm ve Türkiye’de Korporatizm, Füsun Üstel-Sabri Yücesoy (Haz.), İletişim Yayınları, İstanbul, 2. Bask1 (1993), 68, Peyami Safa, 55., Uriel Heyd, Ziya Gökalp’in Hayatı ve Eserleri, Çev. Cemil Meriç, Sebil Yayınevi, İstanbul (1980), 57.

125 Berkes, Türkiye’de Çağdaşlaşma, 465. 
ileri sürmektedir. ${ }^{126}$ Parla, bu düşüncelerinden dolayı Gökalp'i, kapitalizmin oluşumunda ve gelişiminde burjuva sınıfının önemini anlamadığı ve kapitalist sistemi yeterince iyi kavramadığ gerekçesi ile eleştirmektedir. ${ }^{127}$ Gökalp'in önerdiği iktisadi düşünceyi en iyi şekilde tanımlayacak kavram "iktisadi vatanperverlik” tir. Bu nedenle Gökalp, "Bırakınız yapsınlar, bırakınız geçsinler" şeklinde ifade edilen bir doktrinin iktisadi vicdanda bir vatanperverlik duygusu uyandırmasının mümkün olmadığını ileri sürmekte ve bu düşünce sahiplerini İngiliz iktisadının etkisinde kaldıkları için eleştirmektedir. ${ }^{128}$ Gökalp'in ekonomik fikirlerinin oluşmasında, dayanışmacı eğilimli Fransız ekonomist Paul Cauwes ile korumacılığın 1srarlı bir savunucusu olan Alman ekonomist Friedrich List'in etkisi çok büyüktür. ${ }^{129}$ Kısaca, Gökalp'in ekonomik sistem ideali kendi ayakları üzerinde durabilen, kapitalizm ve sosyalizmin rekabet ve sınıf çatışmalarını ortadan kaldıran, dayanışmacı, korumacı ve devletin ekonomide ancak düzenleyici ${ }^{130}$ olarak yer aldığı bir millî iktisat sisteminden ibaret olduğu söylenebilir.

Ziya Gökalp, ekonomik gelişme açısından yabancı sermaye ve yabancı uzmanlara özel bir önem atfetmekte ve Türk milletinin, bir alanda ihtisaslaşma, iş bölümü ve mesleki yapılanma konusunda eksikleri olduğunu belirtmekte ve bu eksikliği gidermek içinde Avrupa'dan yetişmiş uzmanlar getirilmesini önermektedir. ${ }^{131}$ Gökalp, yabancı sermayenin siyasî şartlarla gelmemesi durumunda herhangi bir sakıncasının olmayacağını düşünmekte ve ülke kalkınmasına önemli katkısının olacağını belirtmektedir. ${ }^{132}$ Bunun yanında makineleşme, şirketleşme ve serbest ticaret usulünün ülkelerin gelişmesi açısından önemine değinmekte. ${ }^{133}$ emek ve sermayeyi birbirini tamamlayan iki unsur olarak görmektedir. ${ }^{134}$

İttihat ve Terakki döneminde, milliyetçi ekonomi politikalarının savunuculuğunu yapanların başında Parvus takma adını kullanan Aleksander Helphand geliyordu. İlginç bir şekilde Parvus, Marxist fikirlere sahip olmasına rağmen, Osmanlı'da işçi sınıfının yetersizliği nedeniyle sosyalist anlamda bir devrim yerine, Türk Yurdu dergisinde milliyetçi ekonomi politikaları ile yerli bir ticaret ve sanayi burjuvazisinin yaratılmasını savunuyordu. ${ }^{135}$ Parvus, yabanc1 sermayenin sakıncalarından söz eden yazılarıyla İttihatçıların iktisadî fikirlerinin oluşmasında etkili olmuş ve dış borçlanma nedeniyle, borçlanılandan çok daha fazla paranın dışarıya akıp gitmesinden dolayı ülkede büyük

126 Ziya Gökalp, Fırkaların İçtimaî Tasnifi- Makaleler IV, , Ferit Ragıp Tuncor (Haz.), Kültür Bakanlığı Yayınları, Ankara (1977), içinde, 27.

127 Parla, 199.

128 Mardin, Siyasal ve Sosyal Bilimler, 111.

129 Parla, 86., Heyd, 108-109.

130 Ziya Gökalp, “İktisadi Adem-i Merkeziyet” Makaleler IX, içinde, 147-148., Ziya Gökalp, Türkçülüğün Esasları, Mehmet Kaplan (Haz.), MEB Devlet Kitapları, İstanbul (1975), 180-82.

131 Ziya Gökalp, “Türklerin En Zayıf Noktası ve En Kuvvetli Noktası ” Makaleler IX, içinde, 108., Gökalp’in iktisadi görüşleri ile ilgili olarak bkz: Cavit Orhan Tütengil, 1964-1965 Ders Yllı Sosyoloji Konferansları, 5. Kitap, İstanbul, 122-141., Rıfat Önsoy, "Ziya Gökalp'in İktisadi Görüşleri”, İstanbul Üniversitesi, Edebiyat Fakültesi Tarih Enstitüsü Dergisi (Prof. Tayip Gökbilgin Hatıra Saylsl), Sayı: 12, (1981-1982), 355-366.

132 Ziya Gökalp, "Ecnebi Sermayesi” Makaleler IX, içinde, 165-167.

133 Ziya Gökalp, “Ticaret, "El-Kasib”, Ziya Gökalp Makaleler I, Şevket Beysanoğlu (Haz.), Kültür Bakanlığ1 Yayınları, İstanbul (1976), içinde, 35-36.

134 Ziya Gökalp, “Ticaret, "El-Kasib”, Makaleler I, içinde, 33-34.

135 Zürcher, 182. 
sanayinin gelişmesinin mümkün olmadığını dile getirmiştir. ${ }^{136}$ Galip Haldun' da yabancı sermayenin ülkede giderek yaygınlaştığına dikkat çekmekte ve buna karşılık millî sermayelerin oluşturulmasını önermektedir. ${ }^{137}$ İttihat ve Terakki, 1908 Devriminden sonra ekonomiye daha etkin bir şekilde müdahale etmiş ve bu uygulama daha sonraki yıllarda Alman etkisi ile milli iktisat politikalarına uygun olarak gelişmiştir. ${ }^{138}$

Türkiye'de milliyetçilik fikirlerinin yayılması ve millî iktisat düşüncesinin belirginleşmesi açısından Yusuf Akçura'nın önemi göz ardı edilemez. Gökalp’in aksine, Batı kültürünün bir bütün olarak alınması gerektiğine inanan Akçura, düşüncesini şu sözleriyle somutlaştırmıştır: "Zeppelinve Blerio 'ya çırak olmak istiyorsak, mutlaka Kant ve Kont 'un da şakirdi olmak mecburiyetindeyiz". ${ }^{139}$ $\mathrm{Bu}$ yönüyle Akçura, diğer Jön Türklerden farklı olarak, Osmanlı Devleti'nin son döneminde dünyadaki gelişmeleri daha doğru bir şekilde değerlendirmiş ve milliyetler sorununun en önemli problem olduğunu tespit etmiştir. Bu düşünceden hareketle Jön Türklerin, Osmanlı Birliği kurma fikirlerinin uygulanma şansının olmadığını da ifade etmiştir. ${ }^{140}$ Akçura, ulusal kalkınmanın dayanağını devletin ulusal bir ekonomi siyaseti gütmesinde görüyordu. Bunun içinde, modern ulus devletlerde olduğu gibi Osmanlı Devleti'nde de bir burjuva sınıfının oluşturulması ve devletin esnaf ve memura değil bu sınıfa dayanması gerektiğini ifade etmektedir. ${ }^{141} \mathrm{Bu}$ ifadelerden de anlaşıldığı üzere, Akçura ülkenin ekonomik kalkınması için yerli unsura dayanan bir MüslümanTürk burjuvazisinin yetiştirilmesi gereğine yaptığg vurgularla İttihat ve Terakki'nin uygulamalarına yön verecek fikirleri geliştirmiştir.

İttihat ve Terakki dönemi iktisadî düşünce ve iktisadî uygulamaları etkileyen önemli kişilerden biri de Tekin Alp takma adlı Moiz Cohen'dir. Tekin Alp İslam Mecmuası'nda yer alan "millî iktisat" başlıklı yazısında Friedrich List'i övüyor, onu Almanların "İktisadî Bismarck"1 diye tanıtıyordu. Türklerin siyaset alanında güçlü figürleri olmakla beraber, iktisadi fikirler anlamında önemli kişilerden mahrum olduğunu ve bir an önce bu tür düşüncelerin oluşturulmasını ve bu alanda insanlar yetiştirilmesini önermektedir. ${ }^{142}$ Tekin Alp, Alman milli iktisat akımının dayanışmacı fikirlerinden hareket etmekte ve bu akımın hedefinin fertlerin, devletin ve toplumun bakış açısını değiştirerek, klasik iktisadın birey esaslı yaklaşımına toplumcu bir bakış kazandırmak şeklinde ifade etmektedir. ${ }^{143}$

İttihat ve Terakki döneminde millî iktisat düşüncesinin yayılması açısından cemiyetlerin de önemli bir yeri olmuştur. Bu cemiyetler arasında 1908 yılında kurulan Türk Derneği, 1911'de kurulan Türk Yurdu Cemiyeti ile 1912'de kurulan Türk Ocağını saymak gerekir. Bayur’a göre, Türk Yurdu'nun amaçları arasında yer alan “Türklerin varidat ve teşebbüs sahibi olmalarına hizmet

136 Toprak, 85.

137 Galib Haldun, “Ecnebi Sermayesi ve Bizim Teşebbüsatımız”, İçtihat, 3. Sene, No:48, 1 Haziran 1328, 1111 -1113, Zikreden Toprak, 85.

138 Zürcher, 183.

139 Bayur, 456., Ziya Gökalp ile Yusuf Akçura’nın karşılaştırılması için bkz: Niyazi Berkes, "Unutulan Adam" 1976 Yll Sosyoloji Konferanslarl, 14. Kitap, İstanbul, 194-203.

140 Berkes, Türkiye' de Çă̆daşlaşma, 400.

141 Tekin Alp, “İktisat”, Türk Yurdu, XII, 140 (1333/1917), 3521-22, zikreden Berkes, 468.

142 Tekin Alp, "Milli İktisat”, İslam Mecmuass, Sayı:22, 12 Şubat 1330, s.562, zikreden Toprak, $27-28$.

143 Tekin Alp, “Tesanûtçülük”, Yeni Mecmua. 4 Mayıs 1918, s.336, Zikreden, Mardin, Siyasal ve Sosyal Bilimler, 113. 
etmek" sözü Sabahattin Bey'in düşüncelerinden ilham alındığını göstermesinin yanında o devirde ekonomik hayattaki yabancı egemenliğine yönelik bir vurgu olarak da kabul edilebilir. ${ }^{144}$ Benzer şekilde Türk Ocă̆ 1 Cemiyeti'nin nizamnamesinde de Cemiyetin amac1; "millî serveti korumak ve çoğaltmak için her türlü meslek ve sanat erbabı ile görüsserek İktisadî ve ziraî teşvik ve irşatlarda bulunacak ve bu gibi müesseselerin doğup yaşamasına elden geldiği kadar yardım edilecektir" şeklinde belirlenmiştir. ${ }^{145}$ Bunların yanında yine millî iktisat düşüncesini desteklemek üzere, Osmanlı Sanatkârân Cemiyeti, Millî Fabrikalar Cemiyeti ve Müdafaa-i Maliyye ve İktisadiyye Cemiyetleri ${ }^{146}$ kurulmuştur.

\subsubsection{Milli İktisat Politikası Önerileri}

İttihat ve Terakki'nin ekonomi politikalarını uygulamasının önündeki en önemli engellerden biri yıllardır kapitülasyonlar aracılı̆̆ıyla verilmiş olan bir takım imtiyazlar ve bu imtiyazların batılı devletler tarafından bir baskı ve tehdit unsuru olarak kullanılmasıdır. Bu yapının değiştirilebilmesi için yapılan kanunlaştırma çalışmalarından biri, vakıflara ait bina ve arsaların satılmasına ve parasıyla ihtiyaç olan eğitim ve hayır kurumları yapılmasını öngören 19 Mayıs 1327 tarihli Kanun ile taşınmazlara ilişkin 1913 'te yapılan düzenlemelerdir. ${ }^{147}$ Gayrı menkullerin el değiştirmesine ilişkin bu yasal düzenlemeler toprakta özel mülkiyetin oluşması ve güvenceye alınması açısından önemli bir adım olmuştur. ${ }^{148}$ İttihat ve Terakki tarafından, 1913 yılında çıkarılan Teşvik-i Sanayi Kanun-u Muvakkati ve onu takiben 1914 yılı başlarında çıkarılan Teşvik-i Sanayi Talimatnamesi 149 sanayileşme açısından çok önemli düzenlemelerdir. Bu yasal düzenlemelerle İttihat ve Terakki iktidarı kendi ekonomi politikalarını ve dolayısıyla ülkenin ihtiyacı olan sanayileşmenin sağlanabilmesi için gerekli adımları atarak yeni bir dönemin ilk işaretlerini vermeye başlamıştır. Psikolojik üstünlük ve özgüven açısından, bu kanunlaştırma çalışmaları içinde belki de en önemli olanı 23 Mart 1916 tarihli "müessesatı nafıa ile imtiyazlı şirketler muhaberat ve muamelatında Türkçe istimali" ${ }^{150}$ hakkındaki yasadır. Bu yasa ile ticarî işlemler ve yazışmalarda kullanılan Fransızcanın yerini Türkçe almıştır. Bu yasa hükümlerinin uygulanmaması halinde bu şirketlere el koyma dahil çeşitli yaptırımlar getirilerek işlemlerin Türkçe olarak yapılmasının sağlanması amaçlanmıştır. İmtiyazsız şirketler içinde işlemlerini Türkçe yapmaları için 3 yıllık bir geçiş süresi verilmiştir. ${ }^{151}$ Böylece İttihat ve Terakki, Türkiye'de millî bir hükümetin kurulduğunu ve bu millî hükümetin yegâne unsurunun Türkler olduğu düşüncesini bütün açıklı̆̆ ile ortaya koymuştur.

İttihat ve Terakki döneminde tarım ve köylülük politikalarının iki karşıt düşünce içinde geliştiği görülmektedir. Bunlar büyük çiftçilik ve küçük çiftçilik tartışmalarıdır. Bu dönemde toprak ağası sınıfının tersine küçük çiftçinin ve köylünün durumunun daha kötüye gittiği ileri sürülmektedir. ${ }^{152}$ Ancak bu düşüncelerin aksine, İttihat ve Terakki döneminde köylünün şartlarının iyileştirilmesi

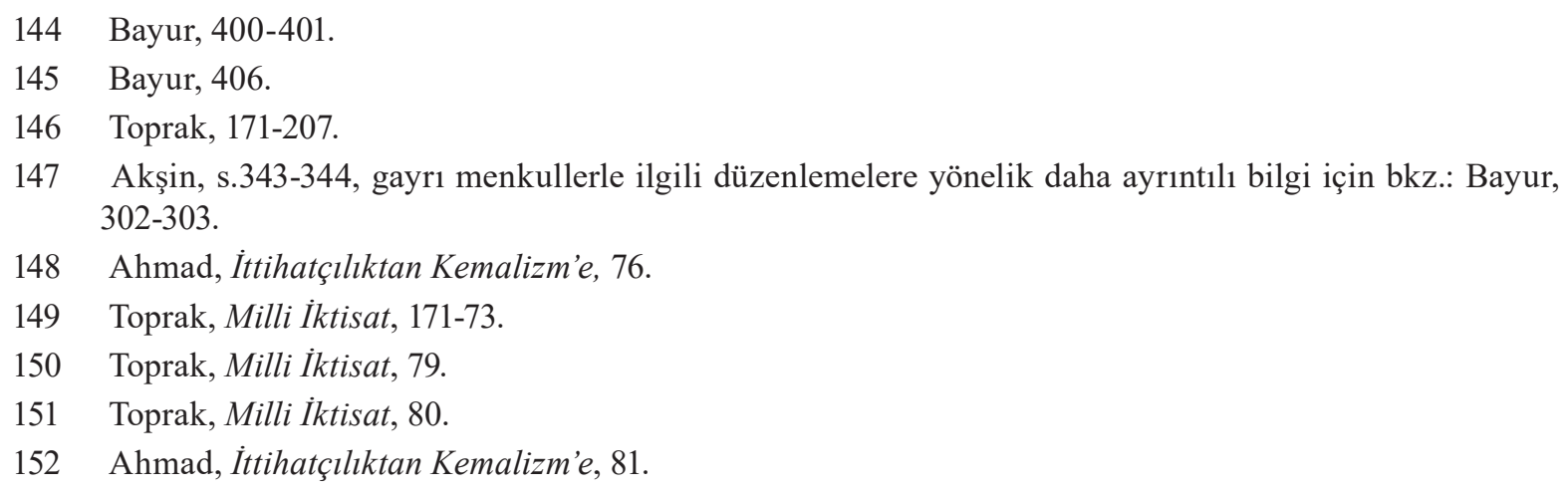


amacıyla, çiftçilere çift hayvanı, tohumluk patates, mısır, pirinç, fasulye verildiği, amele taburları tarlada çalıştırılarak köylüye yardımcı olunmuştur. Ayrıca, hasat, harman ve üretim için makineler ve bağlar için Avrupa'dan göztaşı ve kükürt getirilerek Ziraat Bankası vasıtasıyla dağıtıldığı göz önüne alındığında yukarıdaki değerlendirmeye katılmak mümkün görünmemektedir. ${ }^{153}$ Hayvancılığın geliştirilmesi için, hayvanların ıslah edilmesi, veterinerlik okullarının kurulması, Almanya'dan yetişmiş uzmanlar getirilmesi ve hayvan sağlığı ile ilgili yasal düzenlemeler yapılmıştır. Bunun yanında tarımsal sanayiyi geliştirmek için şeker pancarı ekim alanlarıyla ilgili çalışmalar yapılmış ve bu çalışmaların sonucuna göre de şeker fabrikalarının kurulması ile tarımsal sanayiye ait ürünlerin tanıtımı amacıyla bir ziraat müzesi açılması planlanmıştır. ${ }^{154}$ İttihat ve Terakki'nin tarımı destekleme politikasının bir unsuru olarak Ziraat Bankası Kanunu'nda yapılan değişikliklerle bankanın tarımla birlikte tarımsal sanayiye de kredi açma imkânı getirilmiştir. ${ }^{155}$ Tekin Alp, Ziraat Bankası Kanunu'nda yapılan değişiklikleri önemli bulmakla birlikte ziraî meseleleri çözmek için yeterli olmadığını belirtmekte, batıdaki uygulamaların dikkate alınmasını önermektedir. ${ }^{156}$ Ayrıca, köylülere Ziraat Bankası'ndan doğrudan nakit kredi kullandırılması yerine, köylünün ihtiyacı olan tarımsal aletler, gübre, tohum, ziraî ilaç vb. ihtiyaçlarının temin edilmesinin daha uygun olacağını belirtmektedir. ${ }^{157}$ İttihat ve Terakki,1908 Kongresi'nde ilk kez Türkiye'de çiftçilerin toprak sahibi yapılmalarını gündeme getirerek ${ }^{158}$ tarım politikalarına verdiği önemi göstermiştir. 1911 Kongresi'nde toprak reformu ve tarımsal krediler açısından önemli kararlar alınmış ve 1913 Kongresi'nde de tarım kredilerinin yanında tarım sendikaları kavramı ortaya atılmıştır. ${ }^{159}$

İttihat ve Terakki'nin en önemli amaçlarından biri de gayri müslim ve Levanten tüccar karşısında bir Müslüman Türk tüccarı yetiştirmekti. Bu amaç İttihat ve Terakki'nin kudretli adamlarından Talat Paşa'nın ifadelerinde şu şekilde ifade edilmektedir: "Her savaşta Türk olmayan elemanlar zenginlik sahibi oluyorlardı Türk vatandaşlarsa insan zayiatı verdikleri gibi fakirlik ve zarurete düşüyorlardı. Bu bakımdan yurttaşları ticarete teşvik etmek ve kendilerine kolaylık göstermek gerekli görülmüştür". ${ }^{160}$ Türkiye'de ticaretin genellikle yabanc1ların elinde olduğu, Türklerin ve Müslümanların ticarî hayatta oldukça azınlık kaldıkları birçok yazar tarafından kabul edilmektedir. Quataert, bu değerlendirmeye karşı çıkmakta ve Müslüman tüccarların Osmanlı Devleti'nde sonuna kadar ezici bir çoğunluğa sahip olduğunu ileri sürmektedir. ${ }^{161}$ İttihat ve Terakki'nin Müslüman tüccar yetiştirme politikasının en önemli unsurlarından biri bunları yabancı tüccarlar karşısında korumak şeklinde olmuştur. Kazgan'a göre bunu sağlamanın en önemli yolu savaş döneminde spekülatif kazanç yollarında Müslüman tüccarların yabancılara karşı kayırılması şeklinde olmuştur. ${ }^{162}$ Kazgan'ın bu düşüncesi, Behar'ın “spekülasyon ticareti” adlı makalesindeki şu ifadelerle doğrulanmaktadır. "Ticaretten, inşaattan, irâdın tahvilinden efrâd-ı memleket istifâde

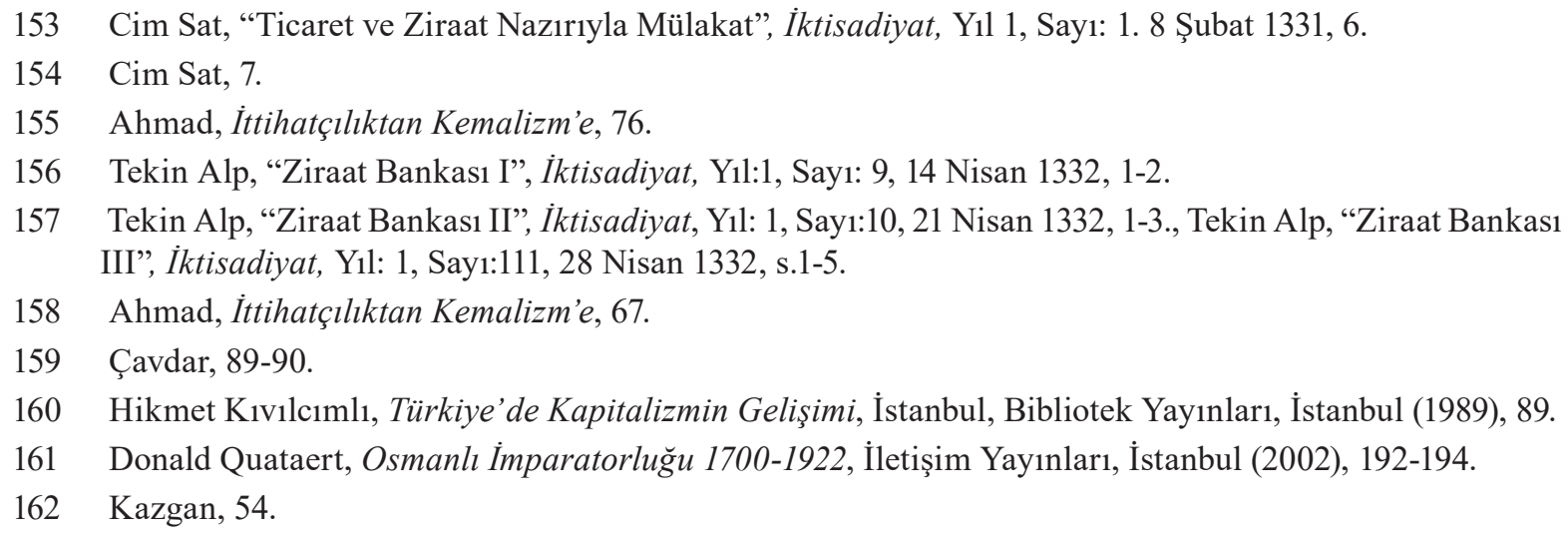


eder. Spekülasyon olmasa servet-i umûmiye terakki etmeyip belki tedenni ve tenezzül eder". ${ }^{163}$ Ticaret politikasının amaçlarından biri de millî bankalar kurmak ve böylelikle ticaret hayatındaki dışa bağımlılığı önlemek şeklinde ortaya konmaktadır. Bu amaçla Osmanlı Bankası'nın yerini almak üzere İtibar-1 Millî Bankası'nın kurulması için büyük gayretler gösterilmiştir. Tekin Alp, "millî banka gibi müesseseler hayat-l iktisadîye ve mâliyemizin millîleşmesine doğru en mühim hatvelerden biridir" ifadesi ile milli bankaların kurulmasının önemine değinmektedir. Ticaretin Türklerin eline geçmesi politikasının halk tarafından da benimsenmesinin bir örneği Konya'da, Konya Millî İktisat Bankası'nın kuruluşunda görülmektedir. Bankanın temel amacı, kâr ve menfaat temin etmek yerine, memleketin çıkarlarını ön plana almak şeklinde ifade edilmiştir. ${ }^{164}$ Diğer bir bankacılık girişimi de İzmir'de İttihat ve Terakki'nin desteğiyle kurulan Bağcılar Bankası'dır. Bu bankanın kuruluşunda İttihat ve Terakki Kulübü'nün ${ }^{165}$ gayretlerinin görülmesini millî iktisat politikası uygulamalarının ticarî alandaki işaretleri olarak kabul etmek gerekmektedir. Bunların yanında, Ticaret Bakanlığı yetkilileri ve diğer ilgili kişilerle birlikte yeni ticarî sisteme yönelik çalışmalar yapmak üzere kurulan İktisadiyat Meclisi, yerli ve yabancı tüccarlarla gerekli bilgi alış verişini sağlamak için bir istihbarat kaleminin kurulması ve Ticaret Odalarının 1slahı ile ticaret borsalarının kurulmasına yönelik çalışmaları zikretmek gerekir. ${ }^{166}$

İttihat ve Terakki'nin ticaretin gelişmesi açısından üzerinde durduğu konulardan biri de kooperatif şirketler uygulaması olup buna ilişkin görüşlerini "İktisadiyâtımızın teâlisine hizmet edecek en mühim âmillerin biri de şüphesiz ki kooperatif şirketlerinin teşkilidir" " 167 şeklinde ifade etmişlerdir. İttihatçıların ticaret politikalarının amacı, yerli sanayii ve yerli tüccarı korumak şeklinde belirlenmiştir. Tekinalp, makalelerinde koruyucu gümrük politikaları ile sanayinin geliştirilemeyeceği eleştirilerine karşı çıkarak hükümetin bu politikasını desteklemekte ${ }^{168}$ ve bu tarifelerin millî iktisadın yerleşmesine kadar devam etmesinin uygun olacağını belirtmektedir. Dış ticarette üretimde kullanılacak malların ithalatına değil, ülkeye faydası dokunmayan malların ithalatına karşı olduğunu ${ }^{169}$ belirtmektedir.

Osmanlı Devleti'nde sanayi alanındaki eksiklikler İttihat ve Terakki'nin önünde önemli bir problem olarak durmaktaydı. İttihatçıların sanayinin geliştirilmesi konusundaki görüşleri imtiyaz ve inhisar usulleri etrafında şekillenmiştir. Bu usullerden hangilerinin daha uygun olacağ konusunda Ticaret, Ziraat ve Sanayi Oda'larından görüş istenmiştir. Bu odalar her iki usule de karşı olduklarını, ancak içinde bulunulan şartlar göz önüne alındığında uygulanabileceğini beyan etmişlerdir. Fakat bu usuller, İttihat ve Terakki içindeki liberal kesimin muhalefeti nedeniyle

\footnotetext{
163 Doktor Yakır Behar, "Spekülasyon Ticareti”, İktisadiyat, Yıl 1, Sayı: 26, 25 Ağustos 1332, 3-4.

164 “Konya Millî İktisad Bankası”, İktisadiyat, Yı1: 1, Sayı: 24, 28 Temmuz 1332, 5-6.

165 “Bağcılar Bankası", Iktisadiyat, Yı1: 1, Sayı: 40, 19 Kanun-u Sani 1332, 3-4.

166 Cim Sat, 7-8.

167 El Barez, "Kooperatif şirketleri”, İktisadiyat, Y1l 1, Sayı: 4, 7 Mart 1332, 2-3.

168 Tekin Alp, "Yeni Ticaret Muahedeleri 1", Iktisadiyat, Y11 1, Say1: 16, 2 Haziran 1332, 1, Ticaret anlaşmalarıyla ilgili olarak bkz.: Tekin Alp, "Yeni Ticaret Muahedeleri II Türkiye -Almanya Ticaret Muahedesi", Iktisadiyat, Y1l:1, Say1: 18, 16 Haziran 1332, 1-3; Tekin Alp, "Yeni Ticaret Muahedeleri III Tiirkiye-Almanya Ticaret Muahedesi", İktisadiyat, Y11 1, Say1: 19, 23 Haziran 1332, 1-4; Tekin Alp, "Yeni Ticaret Muahedeleri IV Merkezi Avrupa ve Biz", Iktisadiyat, Y11 1, Sayı: 22, 21 Temmuz 1332, 1-2; Aynizade Hasan Tahsin, "Gümrük Tarifeleri”, İktisadiyat, Yıl 1, sayı: 1, 8 Şubat 1331, 3-5.

169 Tekin Alp, “Ticaret-i Hâriciyemiz”, İktisadiyat, Y11 1, Sayı: 5, 14 Mart 1332, 1-2.
} 
uygulamaya konulamamıştır. ${ }^{170}$ Millî iktisatçılar, sanayileşmenin gereğine inanmakla birlikte dönemin şartları dikkate alındığında insanların sanayiden ziyade ticarete yöneldikleri görülmektedir. Bu yönelim "Son zamanlarda vuku bulan intibah-ı İktisadî neticesinde hayat-l iktisadîyede ibraz-ı faaliyete başlamış olan unsurların kısm-ı azami ticarete sülük ve intisab ediyor, çabuk zengin olmak dâiyesine düşüyorlar" " ${ }^{171}$ şeklindeki ifadelerle eleştirilmektedir. Tekin Alp, sanayileşme için yabanc1 sermayeye ihtiyaç olduğunu vurgulanmakla birlikte, sanayinin tamamen koruyucu gümrük önlemleriyle desteklenmesini millî iktisat açısından olumsuz bulduğunu belirtmektedir. Sanayinin bu tür koruyucu önlemlerle aşırı derecede korunması halinde, sanayideki işgücü talebi artışının ücretleri artıracağı ve bununda tarımdan sanayiye işgücü akışı nedeniyle ekonominin genel dengesini bozacağına dikkat çekmektedir. Ayrıca daha fazla üretimin, daha fazla fabrika ve daha fazla maden ve arazi işletilmesi ile değil, üretim kaynaklarının verimli bir şekilde kullanılmasıyla mümkün olacağını ifade etmektedir. ${ }^{172}$ İttihat ve Terakki döneminde uygulanan sanayileşme politikaları ile birçok Anadolu şehrinde irili ufaklı sanayi tesisleri oluşmaya başlamıştır. Bu oluşumlar İttihat ve Terakki'nin yayın organlarında büyük bir sevinçle halka duyurulmakta, hem yeni dönemin propagandası yapılmakta, hem de halkın moral gücü canlı tutulmaya çalışılmaktadır. ${ }^{173}$ İttihat ve Terakki döneminde çıarılan Teşvik-i Sanayi Kanunu iktisadi kalkınmada sanayileşmenin önemini göstermesi açısından çok önemli bir aşamadır. ${ }^{174} \mathrm{Bu}$ Kanunla, Osmanlı Devleti'nde, Avrupa sanayileri ile rekabet edebilen büyük ölçekli sanayi kuruluşlarını gerçekleştirmek amaçlanmıştır. ${ }^{175}$ Bütün yapılan bu çalışmalar ve iyi niyetlere rağmen Mehmet Zeki, mevzuatta yer alan teşviklerin sanayileşme için yeterli olmayacağını, bu teşviklerin yanında sermayeye ve teşebbüs erbabı denilen bir girişimci sınıfa ihtiyaç olduğunu belirtmektedir. ${ }^{176}$

Kapitülasyonlar, Düyun-u Umumiye ve Osmanlı Bankası'nın devlet üzerinde kurduğu denetim nedeniyle para ve maliye politikaları İttihat ve Terakki dönemi açısından öncelikli konuların başında gelmektedir. Bu amaçla hükümet dış ticaret ve yabancı yatırımı teşvik etmenin yanında vergi gelirlerini kontrol etmek ve tahsilatını iyileştirerek maliyede bazı düzenlemeler yapmaya çalışmıştır. Fakat bu düzenlemelere rağmen Avrupalı devletlerden ve yabancı yatırımcılardan beklenen destek görülmemiştir. Çünkü yabancılar yeni rejimin milliyetçiliğinden ürkmüşlerdir. ${ }^{177}$ Ülkenin malî durumunun düzeltilmesi için Kamil Paşa Hükümeti'nin programında, ordu harcamalarında ordunun gücünü azaltmadan kesinti yapılacağı, bakanlıklardaki memur sayılarının ve maaşlarının azaltılacağı, biraz borçlanma ve tasarruf yapılarak malî durumun düzeltileceği belirtilmiştir. Bunun yanında yolsuzlukların önüne geçerek devlet gelirlerinin artırılması ile kapitülasyonlarla yabancı şirketlere tanınmış ayrıcalıklar ve önceliklerin kaldırılması için çalışmalar yapılması hedef olarak

Toprak, Milli Iktisat, 172-173.

Tekin Alp, “İstihsalat-1 Milliyeyi artırmak Meselesi”, İktisadiyat, Y1l 1, Sayı: 43, 1 Mart 1332, 2.

Tekin Alp, "İstihsalat-1 Milliyeyi artırmak Meselesi”, 2.

Tekin Alp, “ Memleketimizde Büyük Sanayi”, Iktisadiyat, Y1l 1, Sayı: 33, 3 Teşrin-i Sani, 1332, 1.

A. Gündüz Ökçün, “Teşvik-i Sanayi Kanun-1 Muvakkati 1913”, İktisat Tarihi Yazıları, Sermaye Piyasası Kurumu Yayınları, (1997), içinde 87.

175 A. Gündüz Ökçün, “Teşvik-i Sanayi Kanun-1 Muvakkati 1913”, 88-98., Önceki uygulamalar için bkz.: A. Gündüz Ökçün, "XIX. Yüzyılın İkinci Yansında İmalat Sanayi Alanında Verilen Ruhsat ve İmtiyazların Ana Çizgileri”, Ankara Üniversitesi SBF Dergisi. Cilt: 27, Say1:1, Mart 1972, 135-166.

Toprak, Milli İktisat, 178-179.

Zürcher,180-181. 
belirlenmişti. ${ }^{178}$ İttihat ve Terakki döneminde para politikalarının önündeki en büyük engel olarak görülen Osmanlı Bankası'na ilk tepki Müdafaa-i Maliyye ve İktisadiye Dergisi’nden gelmiştir. Dergi bu nedenle ekonomik bağımsızlık için bir devlet bankasının kurulmasının şart olduğunu ileri sürmektedir. Bu amaçla 1914 yılı başlarında Evkaf Bankası yasa tasarısı meclisten geçirilmiş ve Evkaf Nezaretinin de sermayedarları arasında yer aldığı bir banka kurulmuştur. ${ }^{179} \mathrm{Bu}$ bankanın başarılı olamaması üzerine İtibari Milli Bankası'nın kuruluş çalışmaları başlamıştır. Tekin Alp'e göre "Milli bankanın en mühim vazifesi, en büyük imtiyazl, en esaslı sebep mevcudiyeti banknot ihracl ve aynı zamanda devletin muamelat-ı mâliyesine alet ve vasita olmaktan ibarettir". ${ }^{180}$ İttihatç1lar için milli bankanın kuruluşu para politikasını yürütmenin bir aracı olarak düşünülmektedir. Bunun yanında bankanın kuruluşu ile halkın elinde bulunan atıl kaynakların değerlendirilmesi ve halkta psikolojik bir güven ortamının yaratılması da hedeflenmektedir. Maliye politikalarının etkinliğini artırmak için malî müfettişlik sistemi, Islahat-1 Maliye Komisyonu ile yeni bir merkezi muhasebe sistemi kurulmuş ve bu yolla memurların, bakanlıkların ve dairelerin kamu parasını kullanmaları sıkı bir denetim altına alınmaya çalışılmıştır. ${ }^{181} \mathrm{Bu}$ dönemde para politikasını uygulamayı zorlaştıran bir unsurda tedavülde farklı para sistemlerinin uygulanmasıdır. Bu nedenle yapılması gereken tek para sistemine geçmektir. Ancak bu durumda elinde değersiz para bulunduranların zararına ve hazinenin de bir gelir kaybına uğraması mümkün olmakla beraber böyle bir sisteme geçilmesine en fazla direncin bankalardan geleceği düşünülmektedir. Tekin Alp bu konudaki görüşlerini "hiç bir banka para farkından, acivden temin ettiği istifadeden vaz' geçmek istemez ve binaenaleyh tevhid-i meskukâta hiç bir vakit taraftar olamaz. Bankalar teshilât göstermek şöyle dursun hükümetin bu hususta ittihaz edeceği tedâbiri tesirsiz bırakmak için ellerinden geleni yapacaklardır. Lâkin hükümet azmederse hakkinı terviç etmekten aciz kalmaz" ${ }^{182}$ şeklinde ifade etmektedir. Toprak'a göre, İttihatçılar Birinci Dünya Savaşı yıllarında savaşın finansmanını karşılayabilmek için enflasyonist bir politika izleyerek emisyon yoluyla efektif talebin sürekli artışına neden olmuşlardır. ${ }^{183}$ Özetle, bu dönemde sürekli toprak kayıpları, savaşlar ve kargaşalıklar nedeniyle maliye politikalarından ziyade ağırlıklı olarak para politikalarının uygulandığı söylenebilir.

İttihat ve Terakki döneminde istihdam politikaları açısından çok net çalışmalar ortaya konulduğu söylenemez. İstihdam sorunu genellikle iş̧̧i-işveren ilişkilerinin düzenlenmesi şeklinde ortaya konulmuştur. 1908 Devriminin getirdiği düşünce, ifade ve toplantı özgürlüğünün etkisi ve aşırı fiyat artışları nedeniyle ücret artışı taleplerinden dolayı yüzlerce grev meydana gelmiş, bu grev ve direnişlere karşı İttihat ve Terakki yönetimi ciddi tepkiler göstermiştir. ${ }^{184} 1908$ Devrimi bu işçi grevlerinin yanı sıra emek-sermaye hareketlerindeki çatışmaları da gün ışığına çıkararak bir sınıf kavgası şeklinde örgütsel ve yığınsal bir nitelik kazanmaya başlamış ve İmparatorluğun Avrupa kesiminde yoğunlaşmıştır. ${ }^{185}$ İttihat ve Terakki döneminin en fazla tartışılan kanunlarından biri de

178 Kansu, 201-202.

179 Toprak, Milli İktisat, 137-138.

180 Tekin Alp, "İtibar-1 Millî Bankası", 2.

181 Shaw, 344.

182 Tekin Alp, “Meskukat Meselesi”, İktisadiyat, Y11 1, Sayı: 3, 29 Şubat, 1331, 1-3.

183 Toprak, Milli İktisat, 235-240.

184 Zürcher, 140.

185 Hakk1 Onur, “1908 İşçi Hareketleri ve Jön Türkler”, Yurt ve Dünya, Mart 1977, s.293., zikreden Yavuz Selim Karakışla, “Osmanlı Sanayi İşçisinin Doğuşu 1839-1923”, Osmanlıdan Cumhuriyet Türkiye’sine İş̧iler 1839-1950, D. Quataert, E. J. Zürcher (Ed.), İletişim Yayınları, İstanbul (1998), içinde s.47. 
1909 yılında çıkarılan Tatil-i Eşgal Kanunu’dur. Kanun'la ilgili meclis tartışmalarına bakıldığında, sosyalist milletvekillerinin Kanuna karşı çıktıkları, buna karşılık liberaller ve millî iktisatçıların destek verdikleri görülmektedir. ${ }^{186}$ İttihat ve Terakki'nin grev konusunda en hassas olduğu konu hem askeri hem de ekonomik etkileri nedeniyle demiryolu grevleri olmuştur. Çünkü bu grevler başkentin diğer bölgelerle ilişkisini kesmesinin yanında, kilometre başına ödenecek garanti bedeli nedeniyle devlete de ilave külfet getirmekteydi. ${ }^{187}$

İttihat ve Terakki döneminde kadınların iş hayatına atılmaları ve işgücü açığının kadınlarla telafi edilmeye çalışılması amacıyla, ticaret mektebi alisi tarafından İnas Darülfünunu'nda bir şube açılması kararlaştırılmış ve başvuruların fazlalığ üzerine bir şube daha açılmıştır. ${ }^{188}$ Benzer şekilde, sanayi işletmelerinde çocukların ve kadınların çalıştırılmalarını düzenlemek üzere 1910 yılında bir kanun teklifi verilmiş fakat kanunlaşamamıştır. ${ }^{189}$ Bunun yanında, Türkiye'nin ilk İş Kanunu olarak kabul edilebilecek olan ancak Balkan Savaşları nedeniyle gündeme alınamayan 1911 tarihli Amelenin Suret-i İstihdamına Dair Kanun Teklifi'ni önemli bir düzenleme olarak kabul etmek gerekir. ${ }^{190}$ Tarımsal alanda üretimi artırmak ve toprakları verimli bir hale getirmek için çıkarılan, seferberlik devam ettikçe her köyde müşterek Ameleyi Mükellefe Marifetiyle Tarlaların Suret-i Zer'i Hakkında Talimatname (1330/1914) ile Mükellefıyet-i Zıraiyye Kanunu Muvakkatı'n1 $(1332 / 1916)$ bir anlamda tarımdaki istihdam politikaları örneği olarak görmek mümkündür. ${ }^{191}$ Yukarıdaki ifadelerden de anlaşılacağı üzere iktidarın ve işçilerin istihdam sorununa yaklaşımları yeni istihdam alanları oluşturulmasından ziyade, mevcut hakların ve dengenin korunmasına yöneliktir.

Bu dönemde yabancı sermaye karşısında bir çekingenlik hissedilmesi, yıllardan beri Avrupa sermaye kapitalizminin adeta esiri olmuş bir toplum için normal karşılanabilir bir davranıştır. Ancak İttihatçılar yabancı sermaye karşısında bu anlamda ciddi bir tedirginlik duymamışlardır. Tahsin ve Saka'ya göre bu durumun nedeni, 1908 Devriminin Batı kaynaklı olmasıdır. ${ }^{192}$ Millî iktisatçıların yabancı sermaye ile ilgili karşıtlıkları milli menfaatlere aykırılık gibi soyut bir kavramdan öteye gitmemektedir. Tekin Alp bu konudaki düşüncelerini "Avrupa sermayesinin azami derecede memleketimize celbi taraftarl olduğumuzdan be hususun menfai-i milliye ile telifi

186 A. Gündüz Ökçün, Tatil-i Eşgal Kanunu 1909, Belgeler, Yorumlar, Semaye Piyasası Kurulu Yayınları, Ankara, 2. Bask1 (1996), Kitaba Kanunla ilgili geniş açılamalar ile Meclis-i Ayan ve Mebusan'daki tartışmalar için bkz.; Kanunun grevi yasaklayıp yasaklamadığı ile ilgili farklı görüşler için bkz.: Zafer Toprak, "1909 Tatil-i Eşgal Kamımı Üzerine", Toplum ve Bilim, Sayı: 13, Bahar 1981 s. 141 - 156 ile Mesut Gülmez, "Bir Belge Bir Yorum: 1909 Tatil-i Eşgal Yasası ve Grev”, Toplum ve Bilim, Sayı: 12, Kış 1980, s.50-64.

187 Donald Quataert, Osmanlı Devleti’nde Avrupa İktisadi Yayılımı ve Direniş (1881-1908), Çeviren: Sabri Tekay, Yurt Yayınları, Ankara (1987) 84-85.

188 “Hanımlara Ticaret Dersleri”, Iktisadiyat Mecmuast, Y11 3, Sayı: 65, 27 Eylül 1333, s.8. Zikreden: Toprak, 83.

189 Zafer Toprak, "Sosyal Politika Tarihimizin İlk Önlemler Paketi: Müessesatı Sınaide Çocukların ve Kadınların Çalıştırılması 1910” Toplum ve Bilim, Sayı:27, Güz 1984, 229-233.

190 Zafer Toprak, “Türkiye'de İlk İş Kanunu Teklifi, Amelenin Suret-i İstihdamına Dair Kanun Teklifi 1911 ", Toplumsal Tarih, Sayl:32, Ağustos 1996, 6-10.

191 A. Gündüz Ökçün, Tarımda Çalışma ve Ekme Yükümlülüğü (Mükellefîyyet i Ziraiyye) Belgeler, 19141922, Sermaye Piyasası Kurulu Yayınları, Ankara, 2.Bask1 (1997), Kitaba Kanunla ilgili geniş açıklamalar ile Meclis-i Ayan ve Mebusan'daki tartışmalar için bkz.

192 Kivilcimlı, 75. 
çarelerini tedkik ve taharri edeceğiz" ${ }^{193}$ şeklinde ifade etmektedir. İttihat ve Terakki Gazetesi, ülkenin içinde bulunduğu şartlar nedeniyle ihtiyaç duyulan altyapı yatırımlarının finansmanının yerli sermaye ile gerçekleştirilebilmesinin imkânsız olduğunu, bu nedenle alt yapı yatırımları için apıların yabancı sermayeye ve o sermaye ile teşekkül edecek Osmanlı şirketlerine açılmasını ${ }^{194}$ bir zorunluluk olarak görmektedir. İttihatçılar, yerli ve yabancı sermaye ortaklığı şeklinde bir modeli Millî iktisat politikaları ile bağdaştırmış ve bu modeli kanunlaştırmakta da sorun yaşamamıştır. Bu kapsamda çıkarılan Orman Kanunu ile hükümete bazı ormanları pazarlık suretiyle şirketlere ihale etme yetkisi tanınmış ve bu şirketlerin pay senetlerinin en az yarısının üç ay süreyle yerli sermayedarların kaydına açık bulundurmaları zorunluluğu getirilmiştir. ${ }^{195}$ Yalman'a göre İttihat ve Terakki, Avrupalı devlet ve şirketlerin baskısından kurtulabilmek için belli bir süre onların isteklerine uymak zorundaydı ve böyle de oldu. ${ }^{196}$ İttihatçılar yabancı sermayeden yana olmakla beraber yabancı ülke mallarına karşı birçok boykot eylemi planlamışlardır. Quataert'e göre bu eylemlerin amacı Müslüman Türk tüccarını gayri Müslim tüccarlar karşısında ön plana çıkartma gayretleri olarak değerlendirilebilir. ${ }^{197}$

\subsubsection{Milli İktisat Politikalarına Yönelik Eleştiriler}

İttihat ve Terakki'nin ekonomi politikası uygulamalarına yönelik eleştirilerin içeriklerindeki ideolojik ve düşünsel temaları ortaya çıarmak her zaman için mümkün görünmemektedir. Liberaller tarafından milli iktisatçılara yöneltilen eleştiriler arasında "iaşe meselesi" önemli bir yer tutmaktadır. Bilindiği üzere İttihat ve Terakki bu çalkantılı dönemde iaşe meselesini, Alman modelini esas alarak çözmeye çalışmıştır. Bu meselenin özü, halkın başta ekmek olmak üzere zorunlu ihtiyaçlarının karşılanarak karaborsacılardan kurtarılmasıdır. Bu hizmetlerin sağlanması görevi, İttihat ve Terakki İstanbul Heyet-i Merkeziyesi'ne havale edilmiş ve bu heyete belediyenin ekmek fiyatları için belirlemiş olduğu narh üzerinden 2-3 paralık bir nevi komisyon alma hakkı verilmiştir. Daha sonra elde edilen bu paralarla Millî Mahsulat, Kantariyye ve Ekmekçiler Şirketi adıyla üç şirket kurulmuştur. ${ }^{198} \mathrm{Bu}$ çabalar sonunda hedef milli şirketler ve tüccarlar oluşturmak olsa da durum bu şekilde gelişmemiş̧ir. Bu dönemde İttihatçılar korumacı politikalar sayesinde yetmişin üzerinde şirket kurmuşlardır. Fakat bu politika sayesinde bazı Türklerin büyük servetler yaptığı bilinmekle beraber en büyük payı, Avram ve şürekası, Aslan Franko ve Mahdumları, İsak Kamhi, Bensusam, Nesim Toledeo, Moiz Yunatan, Elias Menahim, Bulgar Pavli gibi Museviler olmuş ve bunların destekleri Kara Kemal'in İaşe Nezaretine kadar yükselmesinde etkili olmuştur. ${ }^{199}$ Benzer şekilde, İttihatçıların 1915 yılında bütün esnafları bir çatı altında birleştirerek Esnaf Cemiyeti’ni kurmaları Cavid Bey tarafından takdir edilmekle beraber, bazı kişiler tarafından

193 Tekin Alp, "Millî İktisada Doğru”, İktisadiyat, Y11 1, Sayı: 1, 8 Şubat 1331, 1-2.

194 “İmtiyazlar”, İttihad ve Terakki, Say1: 8, 23 Ağustos 1908, 4, zikreden: Toprak, Milli İktisat, 83-84.

195 Toprak, Milli Iktisat, 92-93.

196 Ahmet Emin Yalman, Turkey in The World War, New Haven, Yale, U.P. 1930, 59, zikreden: Akşin, 377378.

197 Quataert, Avrupa İktisadi Yayılımı, 121., Avusturya boykotu ile ilgili farklı değerlendirmeler için bkz.: İrtem, Meşrutiyet Doğarken, 300-306, 318; Akşin, 128-129; Yalçın, 65., İtalyanlara karşı uygulanan boykot için bkz.: Shaw, 350., Yunan mallarına karşı uygulanan boykot için bkz.: Bayur, 493-494.; İrtem, 321-23; Cüneyt Okay, “ Müslüman Boykotajı ve Îstiklal-i İktisad-1 Millî Cemiyeti” Toplum Bilim, Sayı: 31, Temmuz 1996, 47-51.

198 Mete Tunçay, Cihat ve Tehcir,1915-1916 Yazıları, Alfa Yayınları, İstanbul (1991),71-72.

199 Kocahanoğlu, Ittihat ve Terakki'nin Sorgulanması, 33. 
şahsi menfaatler uğruna kullanılması ve kendi şahsi gayretleri ile iş yapanlara adeta düşman gözüyle bakılması nedeniyle de eleştirilmektedir. ${ }^{200}$ Aynı eleştiriler Ahmet Rıza tarafından da ileri sürülmüş ve hatta bu yolsuzlukların II. Abdülhamit'i dahi tenzih edecek kadar ileri bir mahiyet aldığ 1 ifade edilmiştir. ${ }^{201}$ Şerif Paşa anılarında, Cemiyeti gayri meşru biçimde servet biriktirmekle, bu firsattan istifade ile keselerini doldurmakla, hiçbir yasal dayanak olmadan zenginlerden, eşraftan, sabık ricalden zorla, tehditle alınan ve "mahiyet-i hakikiyyesi" bilinmeyen paraların Cemiyet içindeki çatışmalara neden olduğunu belirtmektedir. ${ }^{202}$ Müfit Şemsi, İttihat ve Terakki uygulamalarını "Cengiz ve Hülagü, İslam 'in maddi medeniyetine ne yapmışlarsa İttihat ve Terakki de Osmanlı Türklerinin ruhunda onu yapmak, yağma etmek istedi. Rüşvet ve her çeşit hırsılzlığın, vurgunculuğu, katliam, çapul ve yağmayl, katilliği, şeref ve yükselme vasitası ve zenginlik ve servet sebebi kılarak Türklügün fitri yüce saflığın ve yüksek faziletini bozmaya çalıştı ki bu cinayetleri diğer rezilliklerinden hiçbir şekilde aşağı kalmayacak derecede mühim bir cinayettir" " ${ }^{03}$ cümleleri ile eleştirmektedir. İttihat ve Terakki, bu eleştirileri bertaraf etmek amacıyla bir "Men'i İhtikâr Komisyonu" kurulmasını kararlaştırmış 204 ancak bu komisyondan da bir sonuç alınamamıştır. Bu dönemde millî şirketler aracılığı ile Rumeli ve Anadolu Demiryollarının ticarî nakliyat için tahsis ettiği vagonların dağıtımında usulsüzlükler yapılmış ve bu yolla vagon tahsis belgesi alanlar bunu fahiş kârlarla başkalarına satarak aradaki farktan büyük vurgunlar elde etmişlerdir. Mevlanzade Rıfat'ın tabiri ile: "Vagon satmak bendegan ihya edici, mesut edici bir menfaat yolu olmuştu. Reisleri methedenlere yahut makbul nakitlerle kardeşleri memnun edenlere vagon vesikası hediye etmek asri bir ihsan şeklini almuşt. Bu yol ve diğer yollarla harpten evvel on paraya malik olmayan serseriler milyonlara sahip olmuşlardır". ${ }^{205}$ Savaş dönemi vurgunculuğunun etkili olduğu bir diğer alan da ihracat vesikaları ve koli tahsisi yöntemlerinde görülmektedir. Burada da, ihracat yapacak durumu ve yeterliliği olmayan bazı kişiler bir takım ilişkileri kullanarak bu vesikaları temin etmekte ve daha sonra bunları piyasada ihracat yapacak fakat kolisi olmayanlara piyasa fiyatının çok üzerinde fiyatlarla satmaktadır. ${ }^{206}$ Sonuç olarak bu eleştiriler ideolojik ve felsefi düzeyde liberal eleştiriler olarak değerlendirilemese dahi, ticarete yapılan müdahaleler ve belli kesimleri korumak suretiyle serbest rekabet ortamının bozulmasına yönelik eleştiriler olduğundan liberal bir bakış açısını yansıttı̆̆ söylenebilir.

$\mathrm{Bu}$ dönem politikalarına karşı sosyalistler tarafından yöneltilen eleştiriler daha ziyade İttihat ve Terakki'nin Türkçülük politikaları ile işçi haklarına karşı gösterilen sert tutum etrafında şekillenmektedir. Bu nedenle Selanik İşçi Federasyonu ile İttihat ve Terakki arasında kurulan iyi ilişkiler bozulma sürecine girmiş, hatta Federasyon Sosyalist Enternasyonal Başkanlık Kurulu'na gönderdiği 1910 tarihli raporunda iktidarın mutlakiyetçi, milliyetçi ve işçi düşmanı siyasetini şiddetle eleştirmiştir. ${ }^{207}$ İttihat ve Terakki’nin sosyalistlere karşı tutumları Parvus tarafindan Sosyalist

200 Ahmad, İttihatçılıktan Kemalizm'e, 45.

201 Bayur, 240-241.

202 Şerif Paşa, Bir Muhalifin Hatıralarl, Ittihad ve Terakki'ye Muhalefet, Nehir Yayınları, İstanbul (1990), 27., Benzer eleştiriler için bkz.: Yalçın, s.44-45, 318-320.

203 Müfit Şemsi, Şemsi Paşa, Arnavutluk ve İttihad Terakki, El Hakku Yalu vela Yu'la Aleyh, Ahmet Nezih Galitekin (Haz.), Nehir Yayınları, İstanbul (1995), 107.

204 Yalçın, Siyasal Anılar, 318-320.

205 Mevlanzade Rifat, 192-96.

206 Kocahanoğlu, Ittihat ve Terakki'nin Sorgulanması, 450.

207 George Haupt, Paul Dumont, Osmanlı Imparatorluğu'nda Sosyalist Hareketler, Çeviren: Tuğrul 
Merkez'de yapılan bir konuşmada eleştirilmekte ve Türkiye'deki işçilerin, din, yurtseverlik ülküsü ve etnik nefretle bölünmüş oldukları belirtilmektedir. ${ }^{208}$ Özetle sosyalistlerin İttihat ve Terakki'nin milli iktisat politikalarına yönelik eleştirilerinde Marxist ve sosyalist doktrinin çok belirgin olduğunu söylemek biraz güç görünmekle birlikte milliyetçilik duyguları ile işçi haklarına yönelik eleştirilerinde bunu görmek mümkündür.

\subsection{Sosyalist İktisat Politikaları}

\subsubsection{Sosyalist İktisat Düşüncesinin Oluşumu ve Önemli Temsilcileri}

Osmanlı Devleti'nde sosyalist fikirler ve sosyalist hareketin gelişimi incelendiğinde 1908 yılına kadar yapılan bazı örgütlenme ve propaganda girişimlerine rağmen sosyalist hareketin esas gelişiminin 1908'den sonra olduğu görülmektedir. ${ }^{209}$ Osmanlı Devleti'nde sosyalizmi kaldıracak bir toplumsal yapı olup olmadığı sorusuna Ahmad, sosyalizm yanlısı aydınlar olmasına rağmen iyi bir sendika örgütlenmesi ile örgütlü bir işçi sınıfının olmadığ́ şeklinde cevap vermekte ve anayasanın uygulanması yönündeki eylemleri sosyalist eylemlerden ziyade sendika eylemleri olarak tanımlamaktadır. ${ }^{210}$ Osmanlı Devleti'nde sosyalizmin gelişmesine engel olan faktörlerden biri de milliyetçiliktir. Dolayısı ile her bir ulusun kendi devletini kurma hayalinin peşinden koştuğu Osmanlı Devleti'nde, enternasyonalist fikirleri benimseyen sosyalizm gelişmek için uygun bir zemin bulamamıştır. ${ }^{211}$

Haupt ve Dumont'a göre Osmanlı sosyalizmi genelde azınlıklardan oluşan ve homojen bir yapıdan ziyade heterojen özellikler göstermekte ve etnik açıdan bakıldığında Ermeniler, Bulgarlar, Makedonlar, Rum ve Yahudilerden oluştuğu görülmektedir. Türklerin sosyalist örgütlenmesi ancak 1908 'den sonra, Hüseyin Hilmi tarafından kurulan Osmanlı Sosyalist F1rkası ile mümkün olmuştur. ${ }^{212}$ Böylesi karmaşık ve birbiri ile uyumlu olmayan etnik ve sosyal yapı nedeniyle Osmanlı sosyalist hareketi toplumun sorunları konusunda teorik anlamda ortaya ciddi çalışmalar koyamamış, sadece batılı yazarlardan alıntı ve aktarımlarla yetinmiştir. ${ }^{213}$

\subsubsection{Sosyalist İktisat Politikası Önerileri}

Osmanlı sosyalistlerinin iktisadî fikirleri incelendiğinde teorik anlamda bir iktisat politikası geliştirebildiklerini iddia etmek oldukça zor görünmektedir. Sayılgan'a göre bunun nedeni II. Meşrutiyet döneminde sosyalist hareketin bir aydın hareketi olması ve halk tabanına dayanmamasıdır. ${ }^{214}$ Tunçay’a göre Türkiye'de 1908-1925 yılları arasındaki sosyalist hareketler

Artunkal, Gözlem Yayınları, İstanbul (1977), 52-53, Sosyalist Entemasyonal'e gönderilen rapor için bkz.:Belge 6, 77-89.

208 Parvus, Türkiye'de Sosyalizm, 14 Kasım 1910, s.4, zikreden: Panayot Noutsos, "Osmanlı İmparatorluğu'nda Sosyalist Hareketin Oluşması ve Gelişmesinde Rum Topluluğu'nun Rolü, 1876-1925” Sosyalizm ve Milliyetçilik (1876-1923) içinde, 124-25.

209 Haupt ve Dumont, 20.

210 Feroz Ahmad, "Osmanlı İmparatorluğunun Son Dönemlerinde Milliyetçilik ve Sosyalizm Üzerine Düşünceler” Sosyalizm ve Milliyetçilik 1876-1923, içinde,16.

211 Ahmad, "Osmanlı İmparatorluğu'nun Son Dönemlerinde Milliyetçilik ve Sosyalizm Üzerine Düşünceler”, 17.

212 Haupt ve Dumont, 35-36.

213 Haupt ve Dumont, 37-38.

214 Aclan Sayılgan, Türkiye’de Sol Hareketler (1871-1971), Otağ Yayınları, 3. Bask1, «t.y», 63. 
zayıflığının yanında halk tabanında karşılığı olmadığından, ancak bazı aydın çevreler etrafında zemin bulmaya çalışmıştır. ${ }^{215}$ Bu nedenle Osmanlı sosyalistleri, sosyalizme toplumsal bir karşıllık bulmak amacıyla, sosyalizmi İslâmi referanslarla tevil etmeye çalışmışlar ve İslâm'daki zekât kavramı ile sosyal adalet kavramı arasında bir ilişki kurmuşlardır. ${ }^{216}$

Sosyalist düşüncede işçi sistemin merkezinde yer aldığından, Osmanlı sosyalistlerinin üzerinde en fazla durdukları konu işçi hakları olmuştur. Bu nedenle sosyalist grup adına meclise "emeği koruma ve savunma yasa" tasarısı vermişlerdir. Tasarıda çalışma süresinin erkek iş̧̧iler için on saate, 14-17 yaşlarında çocuklar için ise sekiz saate indirilmesi, 14 yaşından küçük ve 70 yaşından büyük olanlara çalışma yasağı getirilmesi, asgari ücretin belirlenmesi, iş kazaları ile ilgili sigorta, grev hakkı gibi taleplerde bulunulmuştur. ${ }^{217}$ Osmanlı Sosyalist Fırkası programında, işçi haklarını kısıtlayan grev ve sendika kanunlarının kaldırılması, işçilerin haftada en az bir gün istirahat etmesi, mesainin günde sekiz saatle sınırlandırılması, 14 yaşından küçük erkek ve 16 yaşından küçük kızların çalıştırılmasının yasaklanması, bir İşçi Nezareti kurulması ve bütün işçi sendikalarına maddi ve manevi yardımlar yapılması gerektiği belirtilmektedir. ${ }^{218}$ Buna karşlık, işgücünün istihdam edileceği yeni yatırım ve iş alanları konusunda herhangi bir öneri getirilmediği görülmektedir. Sosyalist mebuslardan Dimitri Vlahof Efendi “Teşvik-i Sanayi Layihası”nın meclisteki tartışmalarında sanayileşmenin gerçekleşebilmesi için gerekli olan sermaye ve işgücü üzerinde durmakta ve memleketimizde iş̧̧i değil, kalifiye işçi sıkıntısı olduğunu dile getirmekte ve çözüm olarak sanayi mekteplerinin açılmasını önermektedir. ${ }^{219}$

Maliye politikalarına ilişkin sosyalist eleştirilerde vergi konularının ön planda olduğu görülmektedir. Ali Namık, sosyalistlerin vergi ile ilgili görüşlerini açıkladığı bir yazısında, sosyalizm ile artan oranlı vergi arasında bir tezat bulunmadığını ve artan oranlı verginin en adil vergi türü olduğunu belirtmektedir. ${ }^{220}$ Sosyalistler vergilerin artırılması ile devletin gelirlerinin artacağı tezine karşı çıkmaktadırlar. Gerekçe olarak ta gümrük resmine konacak zamdan doğan farkın yine halkın cebinden çıkacağını, böylece geliri azalan halkın daha az tüketeceği, daha az tükettiği için de söz konusu malların tüketimindeki düşüşün vergi gelirlerinde azalmaya neden olacağını ileri sürmektedirler. ${ }^{221}$ Sosyalistler halk üzerindeki vergi yükünün azaltılması için dolaylı vergilerin azaltılmasını önermektedirler. ${ }^{222}$

Sosyalistlerin sanayileşme konusundaki düşüncelerini aktaran Vlahof’a göre, sanayinin gelişmesi için işçilere meslek eğitimi sağlanmalı ve çıarlarını savunabilmeleri için özgürce örgütlenmelerine izin verilmelidir. ${ }^{223}$ Yine Vlahof, Teşvik-i Sanayi Layihası tartışmalarında önemli bir konuya işaret etmekte ve sanayinin sadece bir kanun çıkarmakla geliştirilemeyeceğini bunun

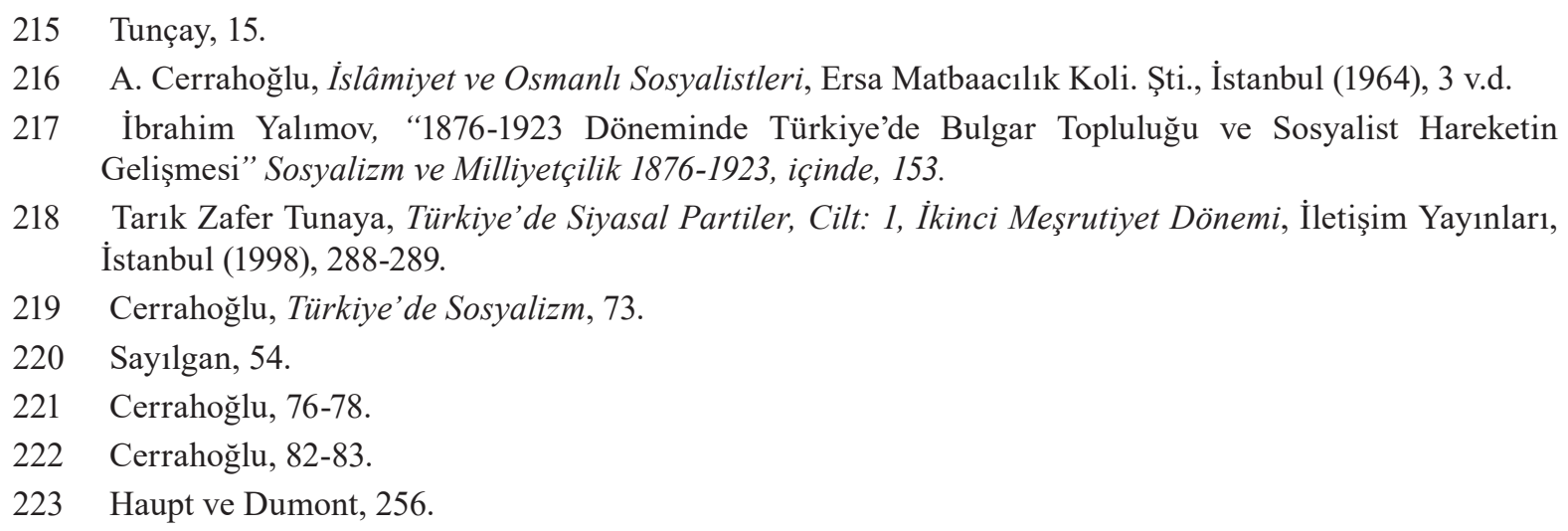


yanında sanayi ürünlerine pazar bulunması gerektiğini belirtmektedir. ${ }^{224}$ Sosyalistler, Türkiye'de sanayinin geliştirilmesi için yabancı sermayenin teşvik edilmesini ve daha fazla sermaye çekmek için açık kapı politikasını savunmaktadırlar. ${ }^{225}$

Sosyalistlerin tarım politikaları incelendiğinde, köylülerin topraklarına sahip olmaları ve bağımsız çalışmalarının önemine işaret edilmekte ve topraklarını kendileri işlemeyen büyük toprak sahiplerinden özel bir vergi alınmasını önermektedirler. Bu verginin uygulanmasına örnek olarak Romanya gösterilmekte ve toprağını işlemeyen toprak sahibinden gelirinin \%26'sı kadar bir vergi alındığ 1 belirtilmektedir. ${ }^{226}$ Diğer taraftan tarımın gelişebilmesi için vergiden muaf tutulacak tarım kooperatiflerinin kurulması, köylülerin kolaylıkla yararlanabilecekleri ucuz kredi imkânlarının sağlanması da sosyalistlerin önerileri arasında yer almaktadır. Bu kredi müessesesinin işletilebilmesi için ipoteğe bağlı kredi düzenlemesine geçilmesi, köylüleri eğitecek tarım okullarının geliştirilmesi ve tarım alanında uzmanlaşmış eğiticiler yetiştirilmesinin önemine işaret etmektedirler. ${ }^{227}$ Sosyalistlerin bu ipoteğe dayalı kredi düzenlenmesi talebi o günün şartlarında ileri bir düşünceyi temsil etmektedir. Çünkü o dönemde toprağın kredi kullanımı açısından ipotek olarak verilmesi ile ilgili hukuki düzenlemeler henüz oluşturulmamıştı. Böylece toprağını işlemek için makine ve teçhizat alımında sermaye sıkıntısı çeken köylünün bu ihtiyacı karşılanarak üretim yapması sağlanmış olacaktır.

\subsubsection{Sosyalist İktisat Politikalarına Yönelik Eleştiriler}

İttihat ve Terakki döneminde sosyalistlere yönelik eleştirilerin en ateşli kişisi olarak Cavid Bey görülmektedir. Cerrahoğlu'na göre Cavid Bey'in Marx'la ilgili eleştirilerinin kaynağ liberal ve sömürgeci Batı burjuva ekonomistlerinin eserleridir. Cavid Bey, İlm-i İktisat adlı eserinde Marxizme yönelik eleştirilerini; "Hiçbir toplumda servet, kişiler arasında, hiçbir şsekilde eşit olarak bölüştürülmemiştir. Bazıları pek zengin, bazıları pek fakir olur, bazıları da orta bir derecede bulunur" ifadeleri ile dile getirmekte ve Marxizm'in mülkiyet hakkını kabul etmemesini ve bütün üretim araçlarının devletin elinde olması teorilerini bilimsel temelden yoksun bir görüş olarak kabul etmektedir. ${ }^{228}$ Ali Kâmi'de sosyalizmin teorik düzeydeki fikirlerine katıldığını belirtmekle beraber uygulamadaki yanlışlıkları nedeniyle bir takım sosyalistleri dahi şüpheye düşecek derecede çatışmaları içinde barındırdığı için eleştirmektedir. ${ }^{229}$ Cavid Bey, 1912 yılında sosyalistlere karşı olan tutumunu Selanik Garı'nın açılış törenindeki bir konuşmasında, yeni yeni gelişen Türk burjuvazisinin işçi örgütlerinin baskılarına dayanamayacağı gerekçesi ile karşı çıkmakta ve bu sınıfın korunması gereğini dile getirmektedir. Ayrıca bu tür eylemlere ve sosyalizmin bu eylemlerdeki etkisini ortadan kaldırmak için yasal düzenleme yapılmasını gerekli görmektedir. ${ }^{230}$ Ahmet Emin, Marx'ın "sosyal devrim nazariyesi”"ni reddetmekte ve ihtilalle işçi sınıfının refaha kavuşacağı iddiasının geçerli olmadığını, birçok ihtilal sonunda geçici olarak kurulan sosyalist idarelerdeki

224 Cerrahoğlu, 74-75.

225 Ahmad, Itttihatçılıktan Kemalizm'e, 31.

226 Haupt ve Dumont, 255.

227 Haupt ve Dumont, 256.

228 Cerrahoğlu, 59-60.

229 Ali Kami, "Sosyalizm Hakkında Tenkidat", Ulum-ı İktisadiye ve İçtimaiye Mecmuası, Cilt: II, Sayı:17, Yı1:2, 707.; Demokrasi ve sosyalizm karşılaştırması için bkz: Asaf Nefi, "Demokrasi ve Sosyalizm ", Ulum-ı İktisadiye ve İçtimaiye Mecmuası, Cilt: II, Sayı: 6, Yıl 1, 161-171.

230 Dumont, Sosyalizm ve Milliyetçilik 1876-1923, içinde 106; Haupt ve Dumont, 56. 
işçilerin durumunu örnek göstermektedir. ${ }^{231}$ Azımzade'ye göre sosyalizmin esas yanılgısı emek ile sermaye arasındaki ilişkiyi tersine çevirmesinden kaynaklanmaktadır. ${ }^{232}$ Osmanlı liberalleri sosyalist iktisat politikalarına doktrinel düzeyde eleştirilerinin yanında, bunların hukuki olarak ta engellenmesi gerektiğini düşünmektedirler.

Gökalp, Marx’a sosyal hadiselerin sebeplerini yalnızca ekonomik nedenlerle açılaması ile halkı yalnız işçi sınıfından ibaret görmesi ve işçi sınıfını diğer sınıfları ortadan kaldıracak bir unsur olarak ele almasından dolayı karşı çıkmaktadır. ${ }^{233}$ Millî iktisatçılar İttihat ve Terakki Gazetesi'nde, sosyalizme, sermaye sınıfının çıkarlarını tehdit ettikleri gerekçesi ile karşı çıkmakta ${ }^{234}$ ve sermayeden yana olduklarını ifade etmektedirler. Özetle Peyami Safa'ya göre, komünizm ve sosyalizm Türk toplumu ile alakasız bir sistemdir ve Türkçüler, İslamcılar ve Batıcılar bu yüzden sosyalizme karşıdırlar. ${ }^{235} \mathrm{Bu}$ ifadelerden de anlaşılacağı üzere, Milli iktisatçıların sosyalizm eleştirilerinde teorik ve doktrinel bir yaklaşımdan ziyade kültürel ve siyasi kaygıların ön plana çıktığı görülmektedir.

\section{Sonuç}

İttihat ve Terakki Osmanlı'da başlayan batılılaşma çabaları ile batıda başlayan milliyetçilik akımlarının bir sonucu olarak ortaya çıkmış ve ülkenin içine düşmüş olduğu durumdan kurtulması için çarenin batılı fikir ve kurumlarda olduğu fikrini benimsemiştir. Ancak, batılı fikir ve kurumlardan hangisinin bu kurtuluşun reçetesi olacağı konusunda İttihat ve Terakki üyeleri arasında tam bir uzlaşma olduğunu söylemek mümkün görünmemektedir. İttihat ve Terakki üyelerinin hangi ideolojik ve felsefî görüşlerden etkilendikleri ile ilgili soruya verilecek en doğru cevap pozitivizm ile Alman idealist düşünür ve felsefecileri olacaktır. Sosyalist düşünür ve felsefecilerden etkilenenler de olmakla birlikte, pozitivist felsefenin etkileri yanında bunlar ihmal edilebilir düzeydedir. İttihatçıların, gerek pozitivist düşünceler ve gerekse diğer batılı fikirlerle tanışmalarında Askeri Tıbbiye, Harbiye ve Mülkiye mektepleri ile bu okullardaki yabancı hocaların etkileri önemli olmuştur. Siyasal sistemlere dair görüşleri ağırlıklı olarak meşrutiyetten yana olup, bu görüşlerin oluşmasında batının aydınlanmacı fikirleri ile Fransız İhtilali'nin etkileri görülmektedir. İslam'ın meşrutiyet sistemine uygun olduğuna dair kavramsallaştırmalarında her ne kadar "meşveret" kavramını kullanıyor olsalar dahi bu kavramı bir meşrulaştırma aracı olarak kullandıklarının kabulü gerekir.

İttihat ve Terakki'yi ekonomik sistem tercihleri açısından liberaller ve milli iktisatçılar olarak iki ana kategoriye ayırmak mümkündür. Bu dönemde sosyalist iktisadi yönelimlerden de bahsetmek mümkün olmakla beraber gerek toplumda ve gerekse İttihat ve Terakki içinde ciddi anlamda bir taraftar buldukları söylenemez. İttihat ve Terakki'nin ekonomik alandaki fikirlerinde başlangıçta liberalizmin daha baskın olduğu söylenebilir. Ancak iktidara gelişlerinden itibaren

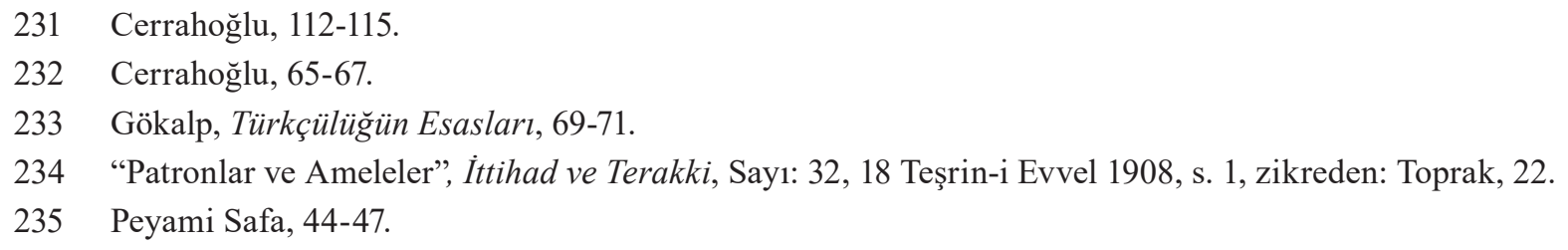


ortaya çıkan savaşlar, ekonomik ve siyasi konjonktür nedeniyle hızlı bir şekilde liberalizmden uzaklaşarak, Alman idealist felsefesine ve bu felsefenin ekonomik alandaki temsilcisi List'in ekonomik düşünceleri doğrultusunda milli iktisada veya daha doğru bir ifade ile korumacı iktisat politikalarına yönelmişlerdir.

$\mathrm{Bu}$ çalışmada, İttihat ve Terakki döneminde liberaller, milli iktisatçılar ve sosyalistler tarafından ortaya atılan iktisat politikası önerileri ve bu öneriler kapsamında ciddi anlamda teorik ve doktrinel düzeyde bir tartışma zemini olacağı düşünülmekteydi. Fakat çalışma boyunca her üç kesim savunucularının da böyle bir tartışma ve fikir üretme zemini ortaya koyamadıkları, dolayısıyla düşünülen anlamda bir iktisat politikası alternatifleri geliştiremedikleri görülmüştür. Teorik ve doktrinel bazda derinlikli çalışmaların ortaya konulabilmesi için toplumun ihtiyaçları ile ortaya konulan sistem arasında karşılıklılık ilişkisinin olması önemlidir. Örneğin batıda kilise ve feodalitenin egemenliğine karşı ortaya çıkan burjuvazi ile liberalizm arasındaki ilişki gibi. $\mathrm{Bu}$ anlamda bakıldığında Osmanlı toplumunda bu tür bir gerilim ilişkisi yaşanmadığı için toplumun iktisadi ve siyasi yapısını değiştirecek yeni bir sınıf ortaya çıkmamıştır. Diğer yandan bu tür dönüşümler uzun bir zaman diliminin yanında iyi bir entelektüel birikimi de gerektirmektedir. Ancak bütün bu şartların bir araya gelmesi halinde teorik ve doktrinel anlamda tutarlı bir siyasi, felsefi ya da ekonomik sistem ortaya konulabilir.

Sonuç olarak, İttihat ve Terakki döneminde özgün bir iktisat politikasının ortaya konulamamasında, batıda olduğu gibi İttihatçıları destekleyecek güçlü bir toplumsal tabanın olmayışı, örnek alınmak istenen ekonomik sistem ya da düşüncelerin geliştiği toplumların tarihsel süreçlerinin yaşanmamış olması, kuruluşlarından çok kısa bir süre sonra kendilerini iktidarda bulmaları, yıkacakları ekonomik ve siyasal sistemin yerine neyi koyacakları konusunda çok fazla fikir yürütmemeleri veya bu fikri yürütecek entelektüellerden mahrum olmaları ve olağanüstü savaş şartlarının önemli etkilerinin olduğu düşünülmektedir. Bu nedenle önerilen veya uygulanmak istenen iktisat politikaları eklektik ve pragmatik olarak kalmış ve ciddi anlamda bir ekonomik sistem tercihinden ziyade konjonktüre göre şekillenmiştir.

\section{Kaynakça}

"Bağcılar Bankası", İktisadiyat, Yı1: 1, Sayı: 40, 19 Kanun-u Sani 1332, 3-4.

"Hanımlara Ticaret Dersleri”, İktisadiyat Mecmuası, Y11 3, Say1: 65, 27 Eylül 1333, 8.

“İmtiyazlar”, İttihad ve Terakki, Sayı: 8, 23 Ağustos 1908, 4.

“Konya Millî İktisad Bankası”, İktisadiyat, Yı1: 1, Sayı: 24, 28 Temmuz 1332, 5-6.

"Muhasebei- İktisadiyye: Serbesti-i Ticaret ve Usul-u Himaye", Osmanlı Ziraat ve Ticaret Gazetesi, 3. Sene, No: 1, 13 Mart 1325

"Patronlar ve Ameleler", Itttihad ve Terakki, Sayı: 32, 18 Teşrin-i Evvel 1908, 1.

Adanır, Fikret. "Osmanlı imparatorluğunda Ulusal Sorun İle Sosyalizmin Oluşması ve Gelişmesi: Makedonya Örneği”, Osmanlı İmparatorluğu'nda Sosyalizm ve Milliyetçilik 18761923, içinde.

Ahmad, Feroz. "Osmanlı İmparatorluğunun Son Dönemlerinde Milliyetçilik ve Sosyalizm Üzerine Düşünceler” Sosyalizm ve Milliyetçilik 1876-1923, içinde.

Ahmad, Feroz. Itttihatçılıktan Kemalizm'e, Çev. Fatmagul Berktay (Baltali), Kaynak 
Yayınları, İstanbul, 4. Baskı (1999).

Âhmed Muhiddin. "Milli Sermaye-Milli Sermaye Teşkilatı”, İslam Mecmuası, Cilt:3, Say1:33,29 Temmuz, 1331, 10

Ahmed Muhtar. "Zirâi Program", Ulum-ı İktisâdiye ve İctimaiyye Mecmuası, C.II, Sayı 9, 1 Eylül 1325, 51-70.

Ahmed Şuayb, Mehmed Câvid ve Rızâ Tevfik. "Mukaddime ve Program", Ulûm-ı İktisâdiyye ve Ítimâ'iyye Mecmuası, C.I, Sayı 1,15 K.evvel 1324, 1-10.

Ahmet İhsan. Matbuat Hatıralarım 1888-1923, I, İstanbul, 1930, 28-30.

Akçuraoğlu, Yusuf. “Gökalp Ziya Bey hakkında Hatıra ve Mülahazalar”, Mehmet Özden (Sad.), Türkiye Günlüğ̈̈, Sayı:20, Güz (1992), 79-81.

Akpolat-Davut, Yıldız. "İkinci Meşrutiyet Dönemi Sosyolojisinin Kaynakları II: İslam Mecmuası ", Türkiye Günlüğ̈̈, Sayı:45, Mart-Nisan 1997, 214-15.

Akşin, Sina. "İttihad ve Terakki üzerine”, Ankara Üniversitesi SBF Dergisi, Sayı: 26, Ankara (1971).

Akşin, Sina. Jön Türkler ve İttihad Terakki, İmge Kitabevi, Ankara, 2. Bask1 (1998).

Ali Kami. "Sosyalizm Hakkında Tenkidat”, Ulum-ı Íktisadiye ve Iç̧timaiye Mecmuası, Cilt: II, Say1:17, Y11:2, 707.

Asaf Nefi. "Demokrasi ve Sosyalizm ", Ulum-ı İktisadiye ve Iç̧timaiye Mecmuası, Cilt: II, Say1: 6, Y11 1, 161-171.

Aynizade Hasan Tahsin. “Gümrük Tarifeleri”, İktisadiyat, Y11 1, say1: 1, 8 Şubat 1331, 3-5.

Baltacıoğlu, İsmail Hakkı. "Ziya Gökalp”, Sosyoloji Konferansları, 5. Kitap, 1964-1965 Ders Ylll, İstanbul, 1-7.

Baydur, Mithat. "Geçmişten Günümüze Prens Sabahattin ve Adem-i Merkeziyetçilik”, Türkiye Günlüğ̈̈, Say1:22, Bahar-1993, 40-45.

Bayraktar, Bayram. "Günümüzde Yeniden Değerlendirilmesi Gereken Bir Düşünür: Prens Sabahattin Bey”, Ankara Üniversitesi, Dil Tarih Coğrafya Fakültesi, Tarih Bölümü, Tarih Araştırmaları Dergisi, Cilt: XVIII, Sayı:29, (1996), 51-61.

Bayur, Y. Hikmet. Türk Inkılabı Tarihi, Cilt: II, Kısım IV, Türk Tarih Kurumu Yayınları, Ankara, 2. Bask1 (1983).

Berkes, Niyazi. "Unutulan Adam” 1976 Yllı Sosyoloji Konferanslarl, 14. Kitap, İstanbul, 194-203.

Berkes, Niyazi. Türkiye'de Çağdaşlaşma, Ahmet Kuyas (Haz.), Yapı Kredi Yayınları, İstanbul, 3. Bask1, (2002).

Cerrahoğlu, A. Islâmiyet ve Osmanlı Sosyalistleri, Ersa Matbaacılık Koli. Şti., İstanbul (1964).

Cim Sat. "Ticaret ve Ziraat Nazırıyla Mülakat”, İktisadiyat, Y11 1, Sayı: 1.8 Şubat 1331, 6-8.

Çağla, Cengiz. "Bir Türk Aydını Olarak Prens Sabahattin Bey”, Türkiye Günlüğü, Sayı:26, 
Ocak/Şubat 1994,30-34.

Çavdar, Tevfik. İttihad ve Terakki, İletişim Yayınları, İstanbul (1991).

Doktor Yakır Behar. "Spekülasyon Ticareti', İktisadiyat, Y11 1, Sayı: 26, 25 Ağustos 1332, $3-4$.

Dumont, Paul. "Yahudi, Sosyalist ve Osmanlı Bir Örgüt: Selanik İşçi Federasyonu”, Osmanlı Imparatorluğu'nda Sosyalizm ve Milliyetçilik (1876-1923), Mete Tunçay, Erik Jan Zürcher (Der.), İletişim Yayınları, İstanbul, 2.Baskı (2000).

Efendioğlu, Ahmet Mehmet. "İttihad ve Terakkinin 1909 Kongresi”, Toplumsal Tarih, Say1: 55, Temmuz (1998).

El Barez. "Kooperatif şirketleri”, İktisadiyat, Y11 1, Sayı: 4, 7 Mart 1332, 2-3.

Elöve, Mustafa E. "Umumi Amme Hukukumuz Bakımından 2. Meşrutiyet Devrinin Türkçülük Cereyanı” Ankara Üniversitesi SBF Dergisi, Cilt:7, Sayı: 1-4, (1952), 218-260.

Ertüzün, Tevfik. "Milliyetçi İktisat Ekolü” Türk Dünyası Araştırmaları (Prof. Dr. Mehmet Eröz’e Armă̆an), Say1:48, Haziran (1987), 163-74.

Faik Nüzhet. "A'şâr", Ulûm-ı İktisâdiye ve İçtimaiyye Mecmuası, Y11: 1, Cilt: III, Say1: 12, 440-442.

Faik Nüzhet. "Temettü Vergisi", Ulûm-ı İktisâdiye ve İçtimaiyye Mecmuası, Y1l: 1, Cilt:1, Say1: 3, 289-314.

Fındıkoğlu, Ziyaeddin Fahri. Türkiye'de İktisat Tedrisatı Tarihçesi ve İktisat Fakültesi Teşkilatı, İsmail Akgün Matbaası, İstanbul (1946).

Galib Haldun. "Ecnebi Sermayesi ve Bizim Teşebbüsatımız", Iç̧tihat, 3. Sene, No:48, 1 Haziran 1328, 1111-1113.

Göçmen, Muammer. Ittihat ve Terakki’nin Son Yılları (1916 Kongre Zabıtları), Eşref Yağcıŏlu (Haz.), Nehir Yayınları, İstanbul (1992).

Gökalp, Ziya. “Ecnebi Sermayesi” Makaleler IX., Şevket Beysanoğlu (Haz.),Kültür Bakanlığ1 Yay. İstanbul (1980).

Gökalp, Ziya. "İktisadi Adem-i Merkeziyet” Makaleler IX.

Gökalp, Ziya. “Ticaret, "El-Kasib”, Makaleler I.

Gökalp, Ziya. “Ticaret, “El-Kasib”, Ziya Gökalp Makaleler I, Şevket Beysanoğlu (Haz.), Kültür Bakanlığı Yayınları, İstanbul (1976).

Gökalp, Ziya. “Türklerin En Zayıf Noktası ve En Kuvvetli Noktası” Makaleler IX.

Gökalp, Ziya. Fırkaların İçtimaî Tasnifi- Makaleler IV, , Ferit Ragıp Tuncor (Haz.), Kültür Bakanlığı Yayınları, Ankara (1977).

Gökalp, Ziya. Inkılapçılık ve Muhafazakarlık, Makaleler IX,

Gökalp, Ziya. Türkçülüğün Esasları, Mehmet Kaplan (Haz.), MEB Devlet Kitapları, İstanbul (1975). 
Gülmez, Mesut. "Bir Belge Bir Yorum: 1909 Tatil-i Eşgal Yasası ve Grev”, Toplum ve Bilim, Say1: 12, Kış 1980, 50-64.

Hanioğlu, M. Şükrü. Bir Siyasal Düşünür Olarak Doktor Abdullah Cevdet ve Dönemi, Üçdal Neşriyat, İstanbul, "t.y."

Haupt, George, Dumont, Paul. Osmanlı Imparatorluğu'nda Sosyalist Hareketler, Çeviren: Tuğrul Artunkal, Gözlem Yayınları, İstanbul (1977).

Heyd, Uriel. Ziya Gökalp’in Hayatı ve Eserleri, Çev. Cemil Meriç, Sebil Yayınevi, İstanbul (1980).

Iacovella, Angelo. Gönye ve Hilal: Ittihad-Terakki ve Masonluk, Çev. Tülin Altınova, Tarih Vakfı Yurt Yayınları, İstanbul (1998).

İbrahim Temo. Ittihad ve Terakki Cemiyeti'nin Teşekkülü ve Hidemat-ı Vataniye ve Inkılab-l Milliye Dair Hatıratım, Mecidiye, Romanya, (1939).

İrtem, Süleyman Kani. Meşrutiyet Doğarken 1908 Jön Türk İhtilali, Osman Selim Kocahanoğlu (Haz.), Temel Yayınları, İstanbul (1999).

İrtem, Süleyman Kani. Yıldız ve Jön Türkler, Ittihad-Terakki Cemiyeti ve Gizli Tarihi, Osman Selim Kocahanoğlu (Haz.), Temel Yayınları, İstanbul (1999).

Jackh, Ernest. Yükselen Hilal, Bir Milletin Yeniden Doğuşu, Türklerin Dünü, Bugünü, Yarını, Çev. Perihan Kuturman, Temel Yayınları, İstanbul (1999).

Kansu, Aykut. 1908 Devrimi, Çev. Ayda Erbal, İletişim Yayınları, İstanbul, 2. Baskı (2001).

Karakışla, Yavuz Selim. “Osmanlı Sanayi İşçisinin Doğuşu 1839-1923”, Osmanlıdan Cumhuriyet Türkiye'sine İş̧iler 1839-1950, D. Quataert, E. J. Zürcher (Ed.), İletişim Yayınları, İstanbul (1998).

Karaman, Deniz. Cavit Bey ve Ulum-ı İktisadiye ve Içtimaiye Mecmuası, Liberte Yayınları, Ankara (2001).

Kars, H. Zafer. 1908 Devriminin Halk Dinamiği, Kaynak Yayınları, İstanbul, 2. Baskı (1997), 35.

Kazgan, Gülten. Tanzimat'tan 21. Yüzyıla Türkiye Ekonomisi, Bilgi Üniversitesi Yayınları, İstanbul (2001).

Kazım Karabekir. Ittihad ve Terakki Cemiyeti, Türdav Ofset, İstanbul (1982).

Keyder, Çağlar. Türkiye 'de Devlet ve Sınıflar, İletişim Yayınları, İstanbul, 3. Baskı (1993),

Kıvılcımlı, Hikmet. Türkiye'de Kapitalizmin Gelişimi, İstanbul, Bibliotek Yayınları, İstanbul (1989).

Kocahanoğlu, Osman Selim. Ittihat ve Terakki'nin Sorgulanması ve Yargılanması, Temel Yayınları, İstanbul (1998).

Koloğlu, Orhan. Osmanlı -Italyan Libya Savaşında Ittihatçılar, Masonlar ve Sosyalist Enternasyonel, Ümit Yayınc1lık, Ankara (1999.

Kösemihal, Nurettin Şazi. “.Le Play Okulu ve Türkiye’deki Etkisi”, Toplum Bilim (Türk 
Toplum Bilimi Özel Saylsı), Say1:2, Ekim (1993), 22-29.

Kuran, Ahmet Bedevi. Inkılap Tarihimiz ve Jön Türkler, Kaynak Yayınları, İstanbul, 2. Bask1 (2000).

Kuran, Ahmet Bedevi. Osmanlı Imparatorluğu'nda İnkılap Hareketleri ve Milli Mücadele, İstanbul (1956).

Kushner, David. Türk Milliyetçiliği’nin Doğuşu (1876-1908), Çev. Şevket Serdar Türet, Rekin Ertem ve Fahri Erdem, Kervan Yayınları, İstanbul (1979).

Lewis, Bernard. Modern Türkiye’nin Doğuşu, Türkçesi, Metin Kıratlı, TTK Yayınları, Ankara, 7. Baskı (1998).

Mardin, Şerif. Jön Türkler'in Siyasî Fikirleri (1895-1908), İletişim Yayınları, İstanbul, 5. Bask1 (1996).

Mardin, Şerif. Siyasal ve Sosyal Bilimler, Makaleler 2, Mümtaz’er Türköne, Tuncay Önder (Haz.), İletişim Yayınları, İstanbul, 6. Baskı (2002).

Mehmed Cavid, “Ecnebi Sermayeleri 2”, Sabah, 15 Teşrin-i Evvel 1908.

Mehmed Cavid, “İstikrazat”, Ulûm-ı İktisâdiye ve İçtimâiyye Mecmuası, Cilt: 3, Sayı: 10, Y11 1, 257-258.

Mehmed Cavid, "İstikrâzât”, Ulûm-ı İktisâdiye ve İçtimâiyye Mecmuası, Cilt: 3, Say1: 11, Y11 1, 386-426.

Mehmed Cavid, "İstikrâzât”, Ulûm-ı İktisâdiye ve İçtimâiyye Mecmuası, Cilt: 3, Sayı: 12, Y11 $1,513-554$.

Mehmed Cavid, "Ticaret Odaları” Ulum-ı İktisadiye ve İçtimaiye Mecmuası, Cilt:I, Sayı: 2, Y1l:1, 200.

Mehmet Memduh, Tanzimattan Meşrutiyete 1, Sadeleştiren Hayati Develi, Nehir Yayınları, İstanbul (1990).

Mevlanzade Rıfat. İtihat Terakki İktidarı ve Türkiye İnkılabının İçyüzü, Yedi İklim Yayınları, İstanbul (1993).

Müfit Şemsi. Şemsi Paşa, Arnavutluk ve Ittihad Terakki, El Hakku Yalu vela Yu'la Aleyh, Ahmet Nezih Galitekin (Haz.), Nehir Yayınları, İstanbul (1995).

Noutsos, Panayot. “Osmanlı İmparatorluğu’nda Sosyalist Hareketin Oluşması ve Gelişmesinde Rum Topluluğu'nun Rolü, 1876-1925” Sosyalizm ve Milliyetçilik (1876-1923) içinde.

Okay, Cüneyt. "Müslüman Boykotajı ve Îstiklal-i İktisad-1 Millî Cemiyeti” Toplum Bilim, Say1:31, Temmuz 1996, 47-51.

Onur, Hakk1. “1908 İşçi Hareketleri ve Jön Türkler”, Yurt ve Dünya, Mart 1977.

Ortaylı, İlber. Osmanlı İmparatorluğunda Alman Nüfuzu, İletişim Yayınları, İstanbul (1998).

Osmanlıdan Cumhuriyet Türkiye'sine İş̧iler 1839-1950, D. Quataert, E. J. Zürcher (Ed.), İletişim Yayınları, İstanbul (1998).

Ökçün, A. Gündüz. "XIX. Yüzyılın İkinci Yansında İmalat Sanayi Alanında Verilen Ruhsat 
ve İmtiyazların Ana Çizgileri”, Ankara Üniversitesi SBF Dergisi. Cilt: 27, Say1:1, Mart 1972, 135 166.

Ökçün, A. Gündüz. “Teşvik-i Sanayi Kanun-1 Muvakkati 1913”, İktisat Tarihi Yazıları, SPK Yayınları, (1997).

Ökçün, A. Gündüz. Tarımda Çalışma ve Ekme Yükümlülüğü (Mükellefìyyet $i$ Ziraiyye) Belgeler, 1914-1922, SPK Yayınlar1, Ankara, 2.Bask1 (1997).

Ökçün, A. Gündüz. Tatil-i Eşgal Kanunu 1909, Belgeler, Yorumlar, SPK Yayınları, Ankara, 2. Bask1 (1996).

Öktem, Ayşenur. "Yerli ve Yabancı Ansiklopedilerde Ziya Gökalp" 1976 Yılı Sosyoloji Konferansları (Ziya Gökalp Özel Sayısı), 14. Kitap, İstanbul, 119-139.

Önsoy, Rıfat. “Ziya Gökalp'in İktisadi Görüşleri”, İstanbul Üniversitesi, Edebiyat Fakültesi Tarih Enstitüsü Dergisi (Prof. Tayip Gökbilgin Hatıra Sayısı), Sayı: 12, (1981-1982), 355-366.

Özbilgen, Erol. Pozitivizmin Klskacında Türkiye, Ağaç Yayıncılık, İstanbul (1994).

Parla, Taha. Ziya Gökalp, Kemalizm ve Türkiye'de Korporatizm, Füsun Üstel-Sabri Yücesoy (Haz.), İletişim Yayınları, İstanbul, 2. Baskı (1993).

Parvus. Türkiye'de Sosyalizm, 14 Kasım 1910, 4.

Petrosyan, Yuriy Asetoviç. Sovyet Gözüyle Jön Türkler, Çev. Mazlum Beyhan-Ayşe Hacıhasanoğlu, Bilgi Yayınevi, Ankara (1974).

Peyami Safa. Türk Inkılabına Bakışlar, Ötüken Neşriyat A.Ş, İstanbul, 2. Baskı (1990).

Prens Sabahattin. Görüşlerim, Ahmet Zeki İzgeör (Haz.), Buruç Yayınları, İstanbul (1999).

Quataert, Donald. Osmanlı Devleti'nde Avrupa İktisadi Yayılımı ve Direniş (1881-1908), Çeviren: Sabri Tekay, Yurt Yayınları, Ankara (1987).

Quataert, Donald. Osmanlı Imparatorluğu 1700-1922, İletişim Yayınları, İstanbul (2002).

Ramsaur, E.E. Jön Türkler ve 1908 İhtilali, Çev. Nuran Yavuz, Sander Yayınları, İstanbul, 2. Bask1 (1982).

Reyhan, Cenk. “Türk Siyasal Düşüncesinde Yol Ayrımı, Aykırı Bir Aydın Prens Sabahattin ve Düşüncesi”, Türkiye Günlüğü, Sayı:21-22, Kış 1992-Bahar 1993, 121-26.

Sayılgan, Aclan. Türkiye'de Sol Hareketler (1871-1971), Otă̆ Yayınları, 3. Bask1, «t.y».

Shaw, Standford, Kural, Ezel. Osmanlı Imparatorluğu ve Modern Türkiye, , Reform, Devrim, Cumhuriyet; Modern Türkiye'nin Doğuşu 1808-1975, Çev. Mehmet Harmanc1, Cilt :2, E Yayınları, İstanbul, 3. Bask1 (2000).

Şerif Paşa. Bir Muhalifin Hatıralart, Ittihad ve Terakki'ye Muhalefet, Nehir Yayınları, İstanbul (1990).

Tanyol, Cahit. "İçtimai Monografi Hazırlıkları, Prens Sabahattin Sosyoloji”, İstanbul Üniversitesi Edebiyat Fakültesi Yayınlan Sosyoloji Dergisi, Say1:4-5, 1947-1949, 145-175.

Tekin Alp. “"Meskukat Meselesi”, Iktisadiyat, Yıl 1, Sayı: 3, 29 Şubat, 1331, 1-3. 

$1332,1$.

Tekin Alp. “ Memleketimizde Büyük Sanayi”, İktisadiyat, Y1l 1, Sayı: 33, 3 Teşrin-i Sani,

Tekin Alp. "Harpten Sulha Intikat Iktisadiyat1-Devlet İktisadiyatı", İktisadiyat Mecmuast, Cilt: 2, Say1: 62-64, 16 Ağustos ve 14 Eylül 1917, 1-3.

Tekin Alp. "İktisat”, Türk Yurdu, XII, 140 (1333/1917), 3521-22.

Tekin Alp. "İstihsalat-1 Milliyeyi artırmak Meselesi”, İktisadiyat, Y11 1, Sayı: 43, 1 Mart 1332, 2.

Tekin Alp. “İtibar-1 Millî Bankası”, İktisadiyat, Y1l 1, Sayı:40, 19 Kanun-u sani, 1331, 1-2.

Tekin Alp. “Millî İktisada Doğru”, İktisadiyat, Y1l 1, Sayı: 1, 8 Şubat 1331, 1-2.

Tekin Alp. "Milli İktisat”, Íslam Mecmuası, Sayı:22, 12 Şubat 1330, 560-562.

Tekin Alp. “Tesanûtçülük”, Yeni Mecmua. 4 Mayıs 1918, 336.

Tekin Alp. “Ticaret-i Hâriciyemiz”, İktisadiyat, Y11 1, Say1: 5, 14 Mart 1332, 1-2.

Tekin Alp. "Yeni Ticaret Muahedeleri II Türkiye -Almanya Ticaret Muahedesi”, Iktisadiyat, Y11:1, Say1: 18, 16 Haziran 1332, 1-3.

Tekin Alp. "Yeni Ticaret Muahedeleri III Türkiye-Almanya Ticaret Muahedesi”, İktisadiyat, Y11 1, Say1: 19, 23 Haziran 1332, 1-4.

Tekin Alp."Yeni Ticaret Muahedeleri IV Merkezi Avrupa ve Biz”, Iktisadiyat, Y11 1,Say1:22, 21 Temmuz 1332,1-2.

Tekin Alp. "Yeni Ticaret Muahedeleri 1", İktisadiyat, Y1l 1, Sayı: 16, 2 Haziran 1332, 1.

Tekin Alp. “Ziraat Bankası I”, İktisadiyat, Y11:1, Say1: 9, 14 Nisan 1332, 1-2.

Tekin Alp. “Ziraat Bankası II”, İktisadiyat, Y11: 1, Say1:10, 21 Nisan 1332, 1-3.

Tekin Alp. “Ziraat Bankas1 III”, Iktisadiyat, Y11: 1, Say1:111, 28 Nisan 1332, 1-5.

Toprak, Zafer. "1909 Tatil-i Eşgal Kanunu Üzerine”, Toplum ve Bilim, Sayı: 13, Bahar 1981, 141-156.

Toprak, Zafer. "Sosyal Politika Tarihimizin İlk Önlemler Paketi: Müessesatı Sınaide Çocukların ve Kadınların Çalıştırılması 1910” Toplum ve Bilim, Sayı:27, Güz 1984, 229-233.

Toprak, Zafer. “Türkiye'de İlk İş Kanunu Teklifi, Amelenin Suret-i İstihdamına Dair Kanun Teklifi 1911 ”, Toplumsal Tarih, Sayı:32, A ğustos 1996, 6-10.

Toprak, Zafer. Türkiye’de Milli Iktisat 1908-1918, Yurt Yayınları, Ankara (1982).

Topuzlu, Cemil. Istibdat-Meşrutiyet-Cumhuriyet Devirlerinde Seksen Yıllık Hatıralarım, Hüsrev Hatemi ve Aykut Kazancıgil (Haz.), İ.Ü.Cerrahpaşa Tıp Fakültesi Yayınları, İstanbul, 2. Bask1 (1982).

Tuna, Korkut. “Gökalp'in Millî Sosyoloji Anlayışı” İstanbul Üniversitesi İktisat Fakültesi Metodoloji ve Sosyoloji Araştırmaları Merkezi, Sosyoloji Konferansları, 21. Kitap, İstanbul (1986), 51-67.

Tunaya, Tarık Zafer. Türkiye'de Siyasal Partiler, Cilt: 1, İkinci Meşrutiyet Dönemi, İletişim 
Yayınlar1, İstanbul (1998).

Tunaya, Tarık Zafer. Türkiye'de Siyasal Partiler, Cilt: III, Ittihad ve Terakki Cemiyeti, Hürriyet Vakfı Yayınları, İstanbul (1989).

Tunçay, Mete. Cihat ve Tehcir, 1915-1916 Yazıları, Alfa Yayınları, İstanbul (1991).

Tunçay, Mete. Türkiye’de Sol Akımlar, 1908-1925, Bilgi Yayınevi, Ankara 2. Bask1 (1967).

Türkdoğan, Orhan. “Ziya Gökalp’te Çağdaşlaşma, İslamlaşma, Türkleşme Akımları ve Millî Devlet Fikrinin Gelişimi”, İstanbul Üniversitesi İktisat Fakültesi Mecmuası, Cilt:36,Sayı: 1-4, (1976-1977).

Tütengil, Cavit Orhan. "Prens Sabahattin (1877-1948)", İstanbul Üniversitesi Edebiyat Fakültesi Yayınları Dergisi, Say1:4-5, 1947-1949, 176-220.

Tütengil, Cavit Orhan. "Ziya Gökalp Üzerine Notlar", İstanbul Üniversitesi Edebiyat Fakültesi Yayınları, Sosyoloji Dergisi, Say1: 10-11, (1955-1956), 101-105.

Tütengil, Cavit Orhan. 1964-1965 Ders Yllı Sosyoloji Konferanslarl, 5. Kitap, İstanbul, 122141.

Uğur, Hidayet. “Jön Türkler’in Çıkardığı Gazeteler 1, Mizan III” Türk Düşüncesi, Cilt: 3, Sayı: 17, 1 Nisan 1955.

Uğur, Hidayet. “Jön Türkler'in Ç1kardığı Gazeteler 1, Mizan II” Türk Düşüncesi, Cilt: 3, Say1:16. 1 Mart 1955.

Uğur, Hidayet. “Jön Türkler’in Çıkardığı Gazeteler 1, Mizan” Türk Düşüncesi, Cilt: 3, Say1: 15. 1 Şubat 1955.

Uğur, Hidayet. "Jön Türkler'in Çıkardığı Gazeteler 3, Terakki” Türk Düşüncesi, Cilt: IV, Say1:20, 1 Temmuz 1955.

Yalçın, Hüseyin Cahit. Siyasal Anılar, Türkiye İş Bankası Kültür Yayınları, İstanbul, 2. Bask1 (2000).

Yalımov, İbrahim. "1876-1923 Döneminde Türkiye'de Bulgar Topluluğu ve Sosyalist Hareketin Gelişmesi” Sosyalizm ve Milliyetçilik 1876-1923, içinde, 153.

Yalman, Ahmet Emin. Turkey in The World War, New Haven, Yale, U.P. 1930.

Zühdî, “İn’ikas-1 Tekalif”, Ulûm-ı İktisâdiye ve İçtimâiyye Mecmuası, Yı1: 3, Say1: 26, 13491362.

Zürcher, Eric Jan. Modernleşen Türkiye’nin Tarihi, İletişim Yayınları, İstanbul, 2.Bask1 (1998). 